University of Nebraska - Lincoln

DigitalCommons@University of Nebraska - Lincoln

Mapping vegetation in Yellowstone National Park using spectral feature analysis of AVIRIS data

\author{
Raymond F. Kokaly \\ U.S. Geological Survey, raymond@usgs.gov \\ Don G. Despain \\ U.S. Geological Survey \\ Roger N. Clark \\ U.S. Geological Survey \\ K. Eric Livo \\ U.S. Geological Survey
}

Follow this and additional works at: https://digitalcommons.unl.edu/usgsstaffpub

Part of the Earth Sciences Commons

Kokaly, Raymond F.; Despain, Don G.; Clark, Roger N.; and Livo, K. Eric, "Mapping vegetation in Yellowstone National Park using spectral feature analysis of AVIRIS data" (2003). USGS Staff -- Published Research. 425.

https://digitalcommons.unl.edu/usgsstaffpub/425

This Article is brought to you for free and open access by the US Geological Survey at DigitalCommons@University of Nebraska - Lincoln. It has been accepted for inclusion in USGS Staff -- Published Research by an authorized administrator of DigitalCommons@University of Nebraska - Lincoln. 


\title{
Mapping vegetation in Yellowstone National Park using spectral feature analysis of AVIRIS data
}

\author{
Raymond F. Kokaly ${ }^{a}{ }^{*}$, Don G. Despain ${ }^{\mathrm{b}}$, Roger N. Clark ${ }^{\mathrm{a}}$, K. Eric Livo ${ }^{\mathrm{a}}$ \\ ${ }^{a}$ Geologic Division, US Geological Survey, M.S. 973, Box 25046, Denver Federal Center, Denver, CO 80225, USA \\ ${ }^{\mathrm{b}}$ Biologic Resources Division, US Geological Survey, Bozeman, MT, USA
}

Received 7 February 2001; received in revised form 12 August 2002; accepted 24 August 2002

\begin{abstract}
Knowledge of the distribution of vegetation on the landscape can be used to investigate ecosystem functioning. The sizes and movements of animal populations can be linked to resources provided by different plant species. This paper demonstrates the application of imaging spectroscopy to the study of vegetation in Yellowstone National Park (Yellowstone) using spectral feature analysis of data from the Airborne Visible/Infrared Imaging Spectrometer (AVIRIS). AVIRIS data, acquired on August 7, 1996, were calibrated to surface reflectance using a radiative transfer model and field reflectance measurements of a ground calibration site. A spectral library of canopy reflectance signatures was created by averaging pixels of the calibrated AVIRIS data over areas of known forest and nonforest vegetation cover types in Yellowstone. Using continuum removal and least squares fitting algorithms in the US Geological Survey's Tetracorder expert system, the distributions of these vegetation types were determined by comparing the absorption features of vegetation in the spectral library with the spectra from the AVIRIS data. The $0.68 \mu \mathrm{m}$ chlorophyll absorption feature and leaf water absorption features, centered near 0.98 and 1.20 $\mu \mathrm{m}$, were analyzed. Nonforest cover types of sagebrush, grasslands, willows, sedges, and other wetland vegetation were mapped in the Lamar Valley of Yellowstone. Conifer cover types of lodgepole pine, whitebark pine, Douglas fir, and mixed Engelmann spruce/subalpine fir forests were spectrally discriminated and their distributions mapped in the AVIRIS images. In the Mount Washburn area of Yellowstone, a comparison of the AVIRIS map of forest cover types to a map derived from air photos resulted in an overall agreement of $74.1 \%$ (kappa statistic $=0.62$ ).

Published by Elsevier Science Inc.
\end{abstract}

Keywords: AVIRIS; Yellowstone National Park; Vegetation; Remote sensing; Spectral feature analysis

\section{Introduction}

Yellowstone National Park (Yellowstone) preserves and protects unique geologic features and biological systems. This paper reports on the application of imaging spectroscopy to map the distributions of vegetation cover types in the Yellowstone ecosystem. The park ecosystem supports many large mammals whose populations and movements are directly and indirectly influenced by the vegetation covering the landscape. In Yellowstone, the distributions of forest stands of whitebark pine have been shown to affect the movements of grizzly bears (Ursus arctos horribilis) (Mattson, Blanchard, \& Knight, 1992). The large fires of

\footnotetext{
* Corresponding author. Tel.: +1-303-236-1359; fax: +1-303-2363200 .

E-mail address: raymond@usgs.gov (R.F. Kokaly).
}

1988 increased interest in fire ecology and demonstrated how dramatically the forests and the state of the ecosystem could change.

Vegetation mapping is a consistent objective of remote sensing for the scientific study and monitoring of ecosystems. The rapid and cost-effective application of remote sensing to map vegetation is one of the important motivations for its utilization in land use planning to replace more time intensive and costly field surveys. Vegetation monitoring using broad band multispectral remote sensing is well established. Recently, innovations in sensors are permitting the connection of remote sensing with methods of laboratory spectroscopy (Clark et al., in press; Tsai \& Philpot, 1998; Zagolski \& Gastellu-Etchegorry, 1996). Now, the knowledge gained from laboratory studies of vegetation spectra and laboratory spectral analysis methods are directly applicable to remote sensing data. 
Imaging spectroscopy refers to data acquired by an airborne or spaceborne imaging spectrometer and the analysis techniques applied to these data in ways that exploit the instrument's ability to resolve absorption features caused by the chemical bonds and physical structure of surface materials (Vane, Duval, \& Wellman, 1993). In comparison to the handful of channels available with multispectral, broad band remote sensing, imaging spectrometers measure the radiation upwelling from a surface in hundreds of contiguous, narrow band width channels (Green et al., 1998). The advantage offered by such spectroscopic measurements is the ability to resolve absorption features and determine their specific wavelength positions and characteristic shapes. These absorption features can be related to the material or materials causing them; thus, the materials occurring in a pixel of imaging spectroscopy data can be identified (see Mustard \& Sunshine, 1999, and the references therein).

Analysis of terrestrial imaging spectroscopy data has been conducted along three major themes: (1) generation and application of "narrow band indices" (Blackburn, 1998; Gao, 1996; Penuelas, Pinol, Ogaya, \& Filella, 1997; Thenkabail, Smith, \& De Pauw, 2000); (2) statistical reduction of "hyperspectral" data to a subset of channels (LaCapra, Melack, Gastil, \& Valeriano, 1996; Martin \& Aber, 1997; Wessman, Aber, \& Peterson, 1989); and (3) matching of the reflectance signatures of known materials to remotely sensed spectra (Adams, Smith, \& Gillespie, 1993; Boardman \& Goetz, 1991; Clark, Gallagher, \& Swayze, 1990; Clark et al., in press (a) Mustard \& Pieters, 1987; Van Der Meer \& Bakker, 1997). This last approach to mapping with imaging spectroscopy exploits not only the greater number of channels available but also takes advantage of the spectrometer's power in resolving absorption features in the spectrum of each pixel. Remote sensing applications of spectral matching to identify materials have been developed in the geological sciences for mineral mapping (King, Clark, \& Swayze, 2000; Swayze et al., 2000). Airborne imaging spectroscopy has also been successfully applied to map vegetation cover (Martin, Newman, Aber, \& Congalton, 1998; Roberts et al., 1998). Some studies in vegetation analysis with spectroscopy have focused on the use of a subset of channels that correspond to the principal absorption features of vegetation (King et al., 2000; Kokaly, 2001; Kokaly \& Clark, 1999; Kokaly, Clark, \& Livo, 1998) or that offer the greatest separability between materials (Asner \& Lobell, 2000).

In this paper, we report on the use of imaging spectroscopy to map biologic materials in Yellowstone using an analysis of spectral features. Vegetation spectra extracted from the AVIRIS data, which were acquired on August 7, 1996, were assembled into a spectral library database for Yellowstone vegetation. The USGS Tetracorder expert system (Clark \& Swayze, 1995; Clark et al., in press (a)) was used to compare the chlorophyll and leaf water absorption features in the AVIRIS pixels to the entries of the spectral library. This approach to mapping vegetation utilized the absorption features caused by the biochemical composition and influenced by the architecture of vegetation canopies. This paper first presents background on the vegetation of Yellowstone and past applications of remote sensing to mapping forest cover. Then, spectral analysis techniques used to detect and map vegetation cover are described. The spectral differences between vegetation cover types in Yellowstone are presented. Finally, the resulting maps of vegetation cover are presented and their contributions to examining the links between the distributions of plant species and large mammal populations are discussed.

\section{Background}

\subsection{Yellowstone vegetation}

The forests of Yellowstone consist of five conifer species (Despain, 1990), including: lodgepole pine (Pinus contorta), whitebark pine (Pinus albicaulis), Douglas fir (Pseudotsuga menziesii), Engelmann spruce (Picea engelmannii), and subalpine fir (Abies lasiocarpa). The temperate forests at high elevations in the park receive large amounts of precipitation during the long, cold winter. At lower elevations, in Yellowstone's relatively drier valleys, grasslands and sagebrush communities predominate. In addition to precipitation, the geology underlying the vegetation in Yellowstone has an influence on the distribution of plants within the park (Despain, 1990). In areas underlain by andesitic rocks, higher nutrient content of the soil supports climax forests of mixed Engelmann spruce/subalpine fir. Douglas fir occurs in moisture-rich areas of the park such as north-facing slopes. Soils derived from rhyolite volcanic flows within the park have relatively low nutrient content; in these areas, the primary forest type is lodgepole pine.

As a result of fire history and soil conditions, the current dominant forest cover in Yellowstone is lodgepole pine. Despain (1990) defined five cover type categories for lodgepole pine based on the forest age, structure, species composition, and fire characteristics (LP0, LP1, LP2, LP3, and LP). The youngest age class is LP0, which represents recently burned forests with an age of zero to 45 years. Since the large fires of 1988, LP0 is a major cover type in the park. Stands of LP1, which are highly resistant to wildfires under normal conditions, range in age from approximately 45 to 150 years. These stands consist of small diameter lodgepole pine with very sparse forest floor vegetation. LP2 cover type stands are closed canopy stands still dominated by lodgepole pine and range from 150 to 300 years in age. The understory of LP2 stands includes Engelmann spruce and subalpine fir seedlings and saplings. Depending on soil conditions, the final seral stage (greater than 300 years of age) of lodgepole pine can be LP or LP3. Stands on rhyolite or other dry soils are dominated by lodgepole pine with some whitebark pine 
possibly occurring in the overstory and understory (this cover type is designated LP). The highly burnable LP3 cover type has an uneven canopy with a mixture of lodgepole pine, Engelmann spruce, subalpine fir, and whitebark pine. The LP3 understory includes small and large spruce and fir seedlings and saplings.

Nonforest vegetation within Yellowstone may be divided into four major groups: grasslands, sagebrush steppes, wetland areas of sedge and willow, and alpine meadows. The distributions of these vegetation types are influenced by precipitation and soil characteristics and, consequently, show a strong relation to elevation. Big sagebrush occurs in dry to mesic areas at middle and lower elevations, such as the Lamar Valley. Silver sage grows in wetter areas above $2100 \mathrm{~m}$, for example the Hayden and Pelican Valleys. Sedge marshes and other wetland vegetation occur in areas with year-long standing water at various elevations throughout the park. Willows and sedges are distributed along streams and near seeps.

\subsection{Reflectance spectra of plants}

Spectroscopy can obtain information about a material by relating the interaction of electromagnetic radiation as a function of wavelength to its chemical composition and physical properties. All vegetation contains the same basic constituents, including chlorophyll and other light-absorbing pigments, water, proteins, starches, waxes, and structural biochemical molecules, such as lignin and cellulose (Elvidge, 1990). All of these components contribute to the reflectance spectra of vegetation (Gates, Keegan, Schleter, \& Weidner, 1965; Knipling, 1970). Fig. 1 shows laboratory reflectance spectra of vegetation foliage in both the fresh state and after being dried in an oven for $24 \mathrm{~h}$. The wavelength regions in which the basic plant components have strong absorption features are indicated on this plot. Because of absorption by chlorophyll, reflectance in the

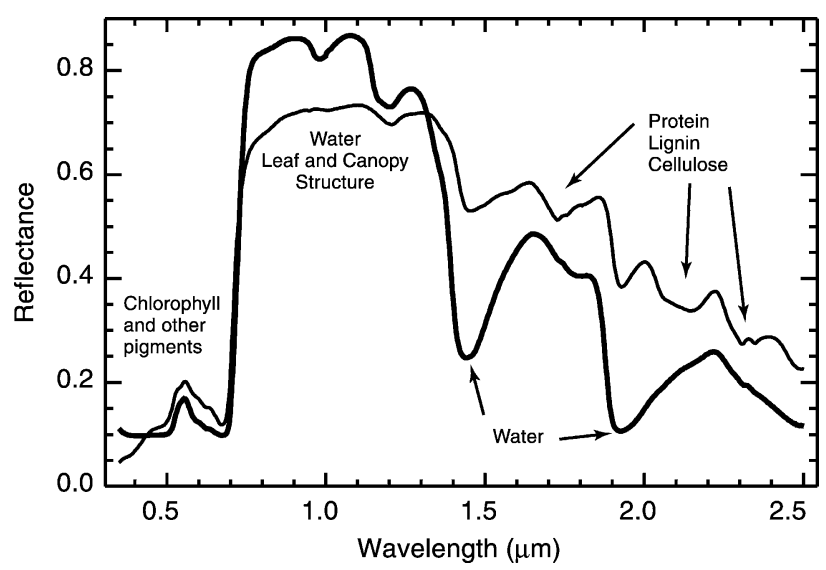

Fig. 1. Laboratory reflectance spectra of an oak leaf in the fresh (thick line) and dry (thin line) states. The causes of major plant absorption features are indicated. visible region of green plants has a maximum at approximately $0.55 \mu \mathrm{m}$ and lower reflectance in the blue $(0.45 \mu \mathrm{m})$ and red $(0.68 \mu \mathrm{m})$.

Beyond visible wavelengths (greater than $0.70 \mu \mathrm{m}$ ), the spectra of fresh plants show a strong rise in reflectance. The region of high plant reflectance at the short wavelength end of the near-infrared $(0.75-1.30 \mu \mathrm{m})$ is called the nearinfrared plateau (NIR-plateau). The high reflectance results from an increased amount of light scattering at cell wall interfaces due to a change in the index of refraction, the absence of absorption by pigments, and the weakening of absorption by water in leaves at these wavelengths. Two absorption features centered near 0.98 and $1.20 \mu \mathrm{m}$ are evident on the NIR-plateau. At $1.40 \mu \mathrm{m}$, another water absorption feature reduces the reflectance. An even stronger water absorption occurs at $1.90 \mu \mathrm{m}$. In dry vegetation, the water absorption features no longer conceal absorption features at $1.73,2.10$ and $2.30 \mu \mathrm{m}$ due to organic bonds in plant biochemicals. Proteins, lignin and cellulose all contribute to these features. $\mathrm{C}-\mathrm{H}, \mathrm{N}-\mathrm{H}$, and $\mathrm{C}-\mathrm{O}$ bonds in these molecules have overtone and combination bands that absorb in the near infrared region of the spectrum (Kokaly, 2001; Peterson \& Hubbard, 1992).

\subsection{Remote sensing of vegetation in Yellowstone}

Despain (1990) used aerial photography over Yellowstone National Park to make a detailed vegetation map showing the distribution of the five major conifer species, the various age classes of lodgepole pine, and nonforest vegetation. Jakubauskas (1996) used Landsat TM data to map the distribution of forest cover types in Yellowstone. He found that different lodgepole pine forest types had differing reflectance characteristics that may allow the discrimination of the youngest, middle, and oldest age forest stands using broad band, multispectral remote sensing data. Landsat TM data were also used by Turner, Hargrove, Gardner, and Romme (1994) to examine spatial patterns of burn severity resulting from the 1988 fires. They found that areas of severely burned forest generally were in close proximity to sources of propagules for plant reestablishment.

\section{Methods}

\subsection{AVIRIS data collection}

For this study, the Airborne Visible/Infrared Imaging Spectrometer (AVIRIS) operated by NASA/JPL was used. AVIRIS collects data in 224 contiguous channels of approximately $10-\mathrm{nm}$ bandpass over the spectral wavelength range of $0.35-2.50 \mu \mathrm{m}$ (from visible light to near-infrared). In Yellowstone, for the mean elevation of $2280 \mathrm{~m}$, the AVIRIS sensor, with an instantaneous field of view of $1 \mathrm{mrad}$, measured pixels with a nominal size of $17.5 \mathrm{~m}$ at nadir. The cross-track pixel sampling at nadir was $15.4 \mathrm{~m}$. The 
along-track sampling was $17.5 \mathrm{~m}$ given the aircraft ground speed of approximately $210 \mathrm{~m} / \mathrm{s}$. The sensor swath width was approximately $9.75 \mathrm{~km}$.

AVIRIS data were acquired on August 7, 1996, at approximately 11:10 a.m. local time, in four flight lines that included the following areas: the Upper and Lower Geyser Basins, the Gallatin Mountain Range, Mammoth Hot Springs, Norris Geyser Basin, the Grand Canyon of the Yellowstone, and the Lamar Valley (Fig. 2). These flight lines were selected in consultation with National Park Service personnel to target areas of primary geologic and biologic interest.

\subsection{AVIRIS data calibration}

In order to convert AVIRIS data from radiance to reflectance, the data were corrected for the influence of several variables, including solar irradiance, atmospheric gas absorption, and atmospheric scattering. The advantages offered by calibrated surface reflectance data compared to uncorrected radiance data include: (1) the shapes of the calibrated spectra are principally influenced by the chemical and physical properties of surface materials, (2) the calibrated remotely sensed spectra can be compared with field and laboratory spectra of known materials, and (3) the

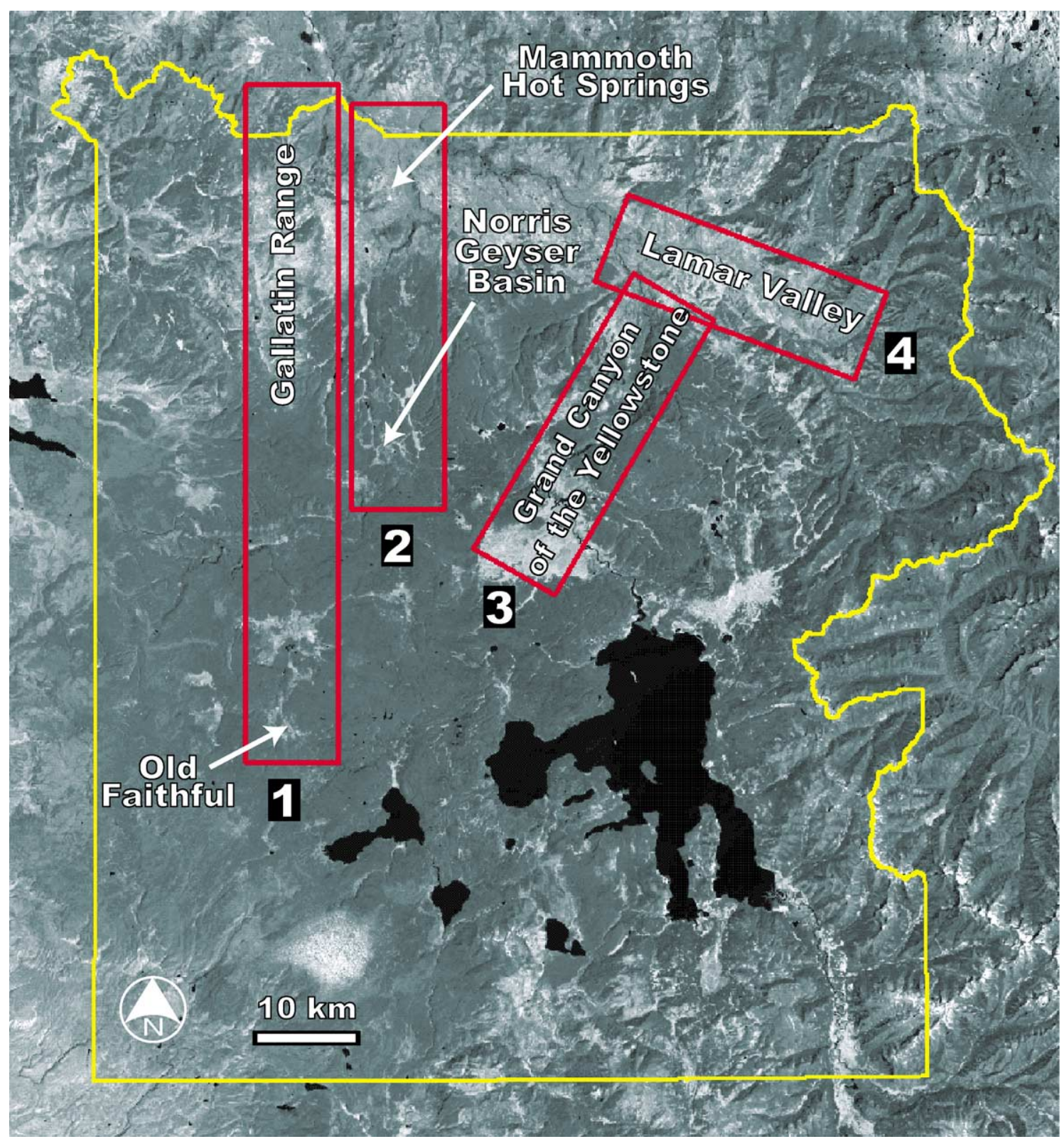

Fig. 2. Coverage of AVIRIS data collected on August 7, 1996 over Yellowstone National Park at 11:10 a.m. (the park boundary is indicated). The four flight lines of approximately $9.75 \mathrm{~km}$ width include: line (1): the Old Faithful area to the Gallatin mountain range; line (2): Norris Geyser Basin to Mammoth Hot Springs; line (3): Grand Canyon of the Yellowstone and Mount Washburn; and line (4): the Lamar Valley. 
calibrated data may be analyzed using spectroscopic methods that isolate absorption features and relate them to chemical bonds and physical properties of materials. Thus, greater confidence may be placed in maps derived from calibrated reflectance data for which errors may be viewed to arise from problems in interpretation rather than incorrect input data.

We employed a two-step procedure for the reflectance calibration as described by Clark et al., in press (b). First, the Atmospheric Removal algorithm (ATREM; Gao, Heidebrecht, \& Goetz, 1993, 1997) was applied to the radiance data. This radiative transfer model removed most atmospheric effects. However, residual atmosphere gas absorption remained in the data. The ATREM data also suffered from an overcorrection of path radiance for wavelengths less than $0.50 \mu \mathrm{m}$. Field reflectance measurements of a ground calibration site were used to reduce the atmospheric residuals. The scattering overcorrection was compensated for by using the darkest ATREM pixels (Rockwell et al., 2002). After application of ATREM, the path radiance correction $(P)$, and the ground calibration multiplier $\left(G_{\mathrm{c}}\right)$, the resulting reflectance data are termed radiative-transfer-groundcalibrated (RTGC).

$R_{\mathrm{RTGC}}=\left(R_{\mathrm{ATREM}}+P\right) G_{\mathrm{c}}$

A gravel staging area, located near Norris Geyser Basin, was utilized for calibration because it was fairly large, homogenous, and did not contain materials with strong absorption features. On the day of the AVIRIS flight, reflectance measurements of this site were made with an Analytical Spectral Devices (ASD) Full-Range field spectrometer. ${ }^{1}$ The mean of the field measurements was calculated and, subsequently, corrected for the absorption features of the Spectralon reference standard (Labsphere, North Sutton, NH). This corrected field measurement was then convolved to match the sampling and bandpass of the AVIRIS instrument. The resulting spectrum $\left(R_{\mathrm{ASD}}\right.$ CAL $)$ was used with the averaged ATREM data over the calibration site $\left(R_{\text {ATREM CAL }}\right)$ and the path radiance correction to generate the multiplicative correction:

$G_{\mathrm{c}}=R_{\mathrm{ASD} \_ \text {CAL }} /\left(R_{\mathrm{ATREM} \_\mathrm{CAL}}+P\right)$

The path radiance correction was derived using ATREM reflectance of a vegetation-covered area in shadow that was located close to the calibration site (for examples, see Rockwell et al., 2002).

Fig. 3a shows the radiance, ATREM derived reflectance, and the RTGC reflectance for the calibration site. Fig. 3b compares ATREM and RTGC reflectance spectra from a patch of bare soil in the same scene, approximately

\footnotetext{
${ }^{1}$ Use of trade names does not constitute endorsement by the US Geological Survey.
}

$2 \mathrm{~km}$ to the east. The atmospheric residuals are much reduced in the RTGC reflectance spectrum. Also, the reflectance in the visible region appears to be free of the overcorrection of the scattering that had forced a strong downturn at short wavelengths in the ATREM data.

\subsection{Spectral feature analysis and mapping methods}

The approach to vegetation mapping taken in this study is to compare the absorption features in the spectra of known vegetation cover types to the spectral features in each pixel of AVIRIS data. The following sections present the critical parts of this approach: (1) techniques of spectral feature analysis used to isolate and normalize absorption features in reflectance data, (2) the creation of a spectral library of vegetation cover in Yellowstone, and (3) the use of a spectral feature fitting algorithm and expert system rules in the USGS Tetracorder system to generate vegetation maps.

\subsubsection{Spectral feature analysis}

In order to compare the shapes of the absorption features, this study uses a method of normalization called continuum removal. Continuum removal, or baseline normalization, is a method that has been commonly used in laboratory infrared spectroscopy (Ingle, 1988). This technique has been applied to terrestrial imaging spectrometer data to map the distribution of minerals and vegetation by comparing remotely sensed absorption band shapes to those in a reference spectral library (Clark et al., 1990; Mustard \& Sunshine, 1999). In continuum removal, the continuum is simply an estimate of the other absorptions present in the spectrum, not including the one of interest (Clark, 1999; Clark \& Roush, 1984).

To illustrate the application of continuum removal, the differences in the chlorophyll absorption features in the mean AVIRIS reflectance spectra of two forest types (shown in Fig. 4a) are used. By applying linear continuum removal (using AVIRIS channels at 0.50 and $0.78 \mu \mathrm{m}$ as the endpoints), it is easily seen that the reflectance from the Douglas fir has a deeper chlorophyll absorption feature than lodgepole pine (Fig. 4b). Scaling of absorption features to the same band depth at the band center facilitates visual comparison of the shapes. An example of this is shown in Fig. 4c. The scaling reveals that, in addition to the greater band depth, the reflectance spectrum of Douglas fir has a wider chlorophyll absorption feature compared to lodgepole pine. The depths at each wavelength in the chlorophyll features of the lodgepole pine and Douglas fir spectra and the general widths of the features (the calculated full-widthat-half-maximum) were found to be significantly different using a standard Student's $t$-test $(\alpha=0.05)$. The observable spectral differences between these two conifers suggest that spectroscopic remote sensing may discriminate conifer forest cover types based on subtle variations in their reflectance spectra. 
a

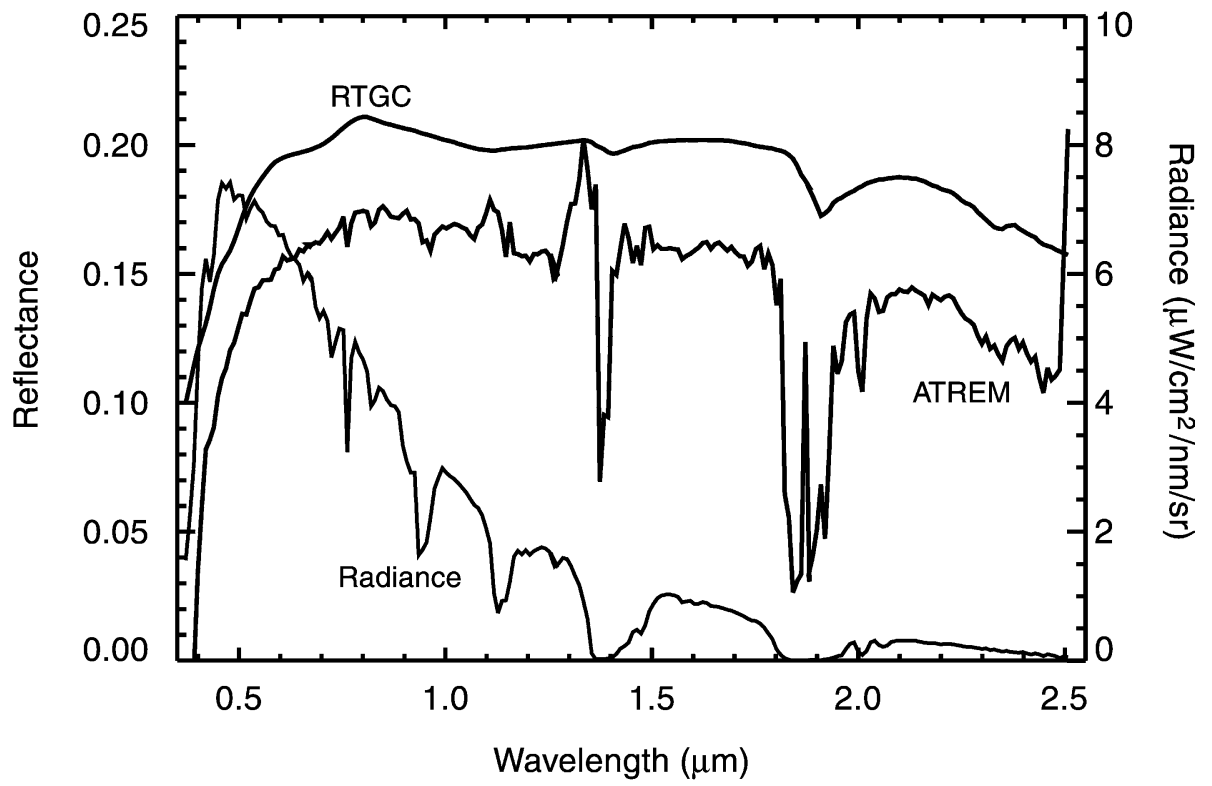

b

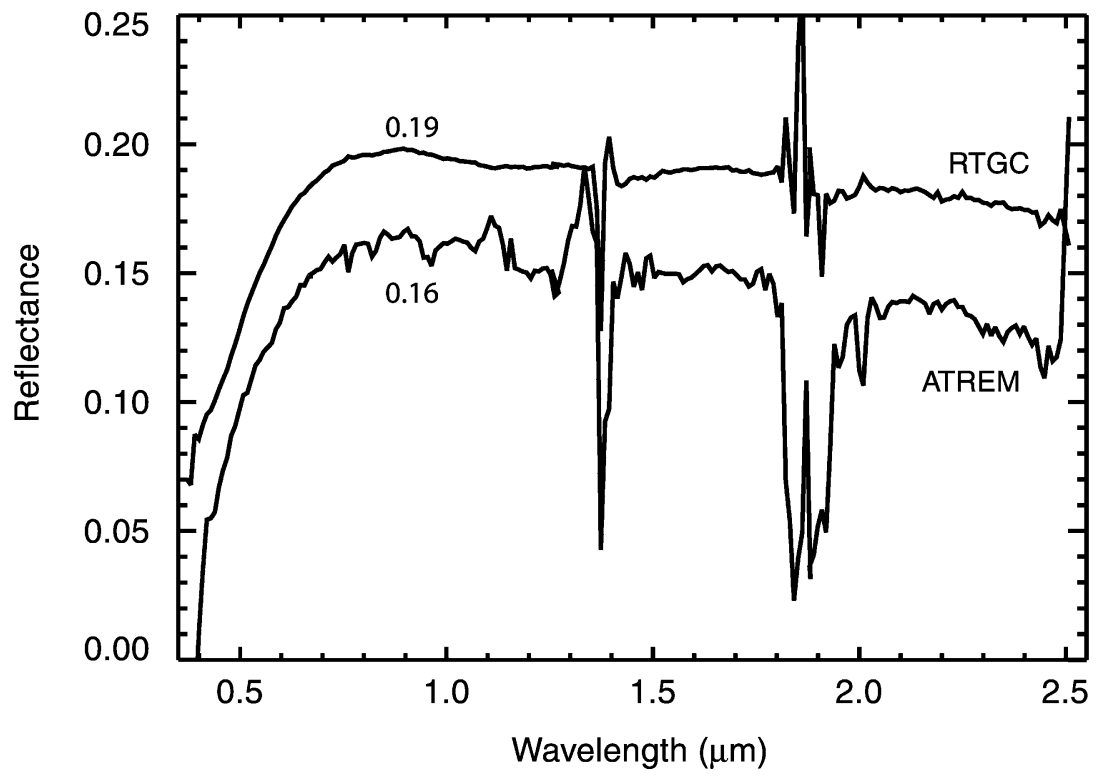

Fig. 3. (a) Norris gravel staging area calibration site radiance, ATREM corrected reflectance, and radiative-transfer-ground-calibrated (RTGC) reflectance. (b) The ATREM and RTGC reflectance for an area of bare soil approximately $2 \mathrm{~km}$ from the calibration site, with reflectance levels given at $0.95 \mu \mathrm{m}$. The irregularities at 1.4 and $1.9 \mu \mathrm{m}$ in the RTGC spectrum are due to uncorrected effects of atmospheric water vapor.

\subsubsection{A spectral library for Yellowstone vegetation}

The major cover types in Yellowstone were identified during a field survey. These cover types included all significant forest cover types: lodgepole pine, whitebark pine (WB), Douglas fir (DF), and a mixed Engelmann spruce/subalpine fir category (SF). Because lodgepole pine covers the greatest area in the park and is the major colonizing species on recently disturbed ground, several age classes of lodgepole pine were used (LP0-3, LP). Areas of these forest types were located in AVIRIS images and pixels were selected to define training sites. In addition, training sites for many types of nonforest vegetation were identified. These nonforest types included sagebrush, willow, Idaho fescue grasslands, lush sedge habitats, and wetland areas.

To define spectral signatures of these vegetation types, pixels in the AVIRIS data covering these vegetation types were averaged together to generate representative spectra. Thirty-eight training sites were identified in the AVIRIS data. For some vegetation cover types, more than one training site was used. Table 1 lists the forest cover types (boldface entries indicate the spectra used in figures in this 
a

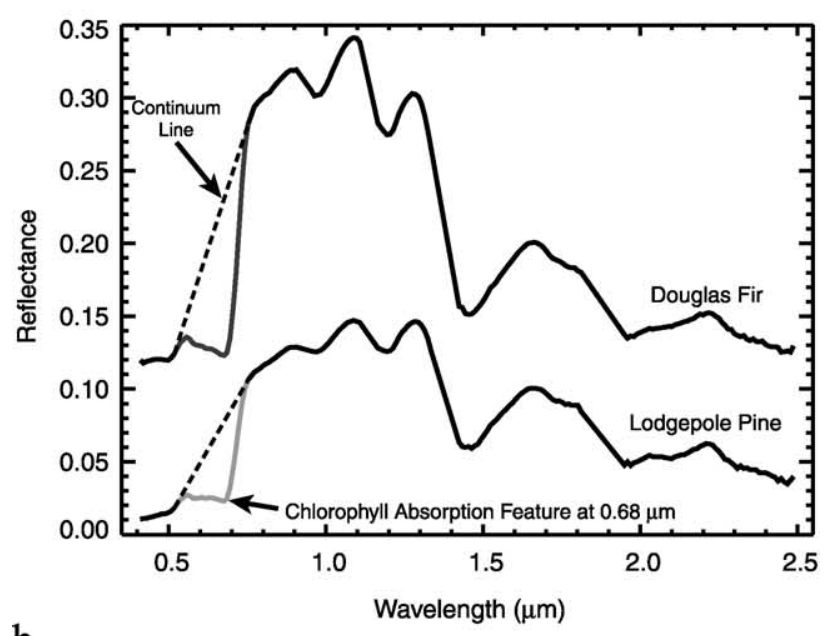

b

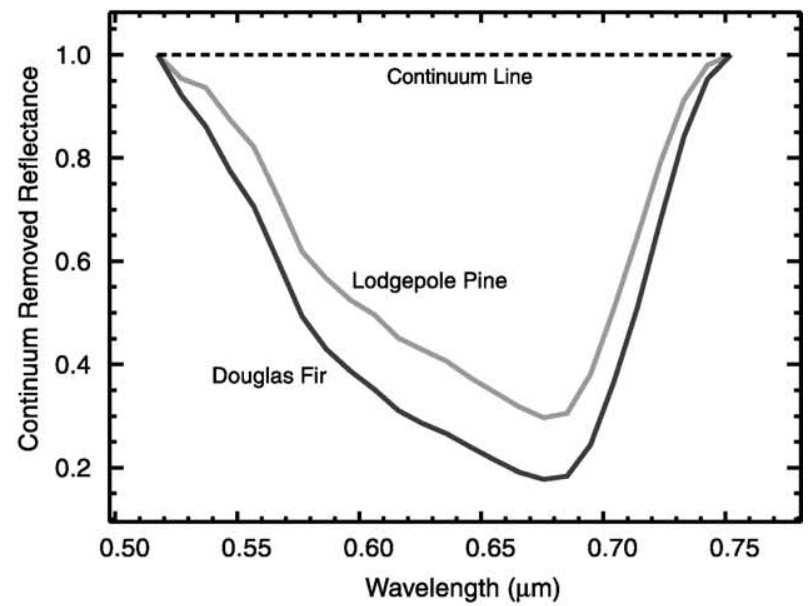

c

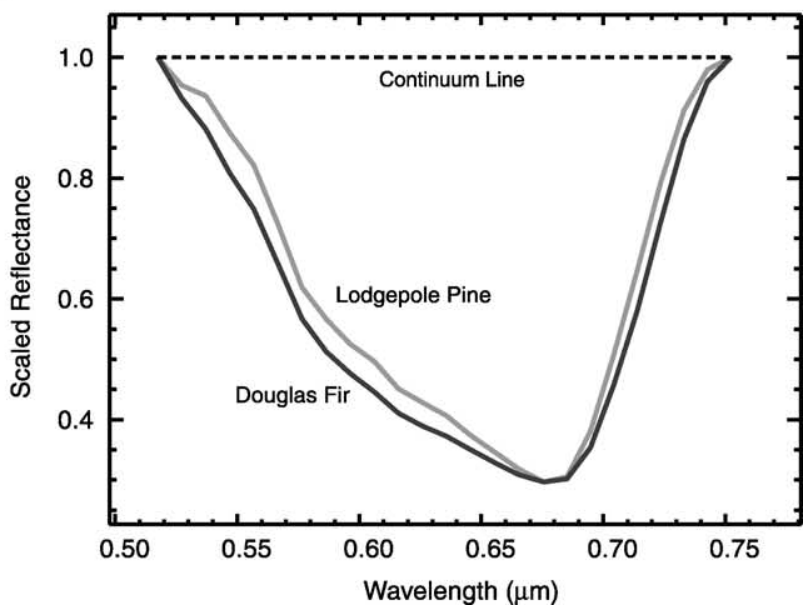

Fig. 4. AVIRIS RTGC mean reflectance spectra of Douglas fir and lodgepole pine with associated continuum lines (a) in which their spectra are offset by 0.1 in reflectance; continuum removed chlorophyll absorption feature spectra (b); scaled chlorophyll absorption features (c).

paper). Table 2 lists the nonforest cover types and the names used to label the subsequent plots. These averaged AVIRIS spectra for the vegetation cover types listed in Tables 1 and
2 comprise the reference spectral library used with the Tetracorder expert system in this study. Although the atmospheric correction and ground calibration of AVIRIS were performed, some channels were deleted a priori from the mapping analysis (and plotted spectra in this paper) because of residual atmospheric effects (channels 1-2, 43, 59-62, 81-84, and 106-113) and detector overlaps (channels $32-33$ and 95-97).

\subsubsection{The USGS tetracorder expert system}

Tetracorder is an expert system that compares the spectra of unknown materials to the spectra of known materials listed in a spectral library (Clark et al., 1990, in press (a); Clark \& Swayze, 1995). Continuum removal is applied to spectra to isolate specific absorption features and remove the effects of changing slopes and overall reflectance levels. A linear least-squares fitting algorithm is used to compare the continuum removed absorption features in each library reference spectrum to the features present in the spectrum of the unknown material (or pixel of imaging spectrometer data). The goodness of fit between the continuum removed spectral features of the library and the unknown spectrum is assessed using the correlation coefficient ${ }^{r}$ calculated by the least-squares fitting algorithm. The correlation coefficient is referred to as the "fit" value. The Tetracorder system can be instructed to make further refinements using a set of expert system rules, such as threshold values on band depths,

Table 1

Spectral library entries of forest cover types

\begin{tabular}{llr}
\hline Forest cover type & Training site location & $\begin{array}{r}\text { Number } \\
\text { of pixels } \\
\text { averaged }\end{array}$ \\
& & 114 \\
Douglas fir & Mammoth (Line 2) & 84 \\
Douglas fir & Gallatin Range (Line 1) & 807 \\
Douglas fir & Lamar Valley (Line 4) & 207 \\
Whitebark pine & Mt Washburn (Line 3) & 34 \\
Whitebark pine & Gallatin Range (Line 1) & 105 \\
Engelmann spruce/subalpine fir & Mt Washburn (Line 3) & 18 \\
Engelmann spruce/subalpine fir & Mt Washburn (Line 3) & 20 \\
Engelmann spruce/subalpine fir & Gallatin Range (Line 1) & 257 \\
Engelmann spruce/subalpine fir & Gallatin Range (Line 1) & 99 \\
Engelmann spruce/subalpine fir & Gallatin Range (Line 1) & 126 \\
Aspen & Lamar Valley (Line 4) & 15 \\
Lodgepole pine age class 0- & Mammoth (Line 2) & 371 \\
$\quad$ moderate regrowth & & \\
Lodgepole pine age class 0- & Mammoth (Line 2) & 56 \\
$\quad$ vigorous regrowth & & \\
Lodgepole pine age class 1 & Mt Washburn (Line 3) & 72 \\
Lodgepole pine age class 1 & Mammoth (Line 2) & 144 \\
Lodgepole pine age class 1 & Norris (Line 2) & 135 \\
Lodgepole pine age class 1 & Mammoth (Line 2) & 129 \\
Lodgepole pine age class 2 & Mammoth (Line 2) & 30 \\
Lodgepole pine age class 2 & Mammoth (Line 2) & 128 \\
Lodgepole pine age class 3 & Norris (Line 2) & 132 \\
Lodgepole pine age class 3 & Mt Washburn (Line 3) & 52 \\
Lodgepole climax age class & Norris (Line 2) & 148 \\
Lodgepole pine meadow mix & Mt Washburn (Line 3) & 153 \\
\hline Boldace indicte & & \\
\hline
\end{tabular}

Boldface indicate entries used in figures of reflectance spectra in this paper. 
Table 2

Spectral library entries of nonforest cover types

\begin{tabular}{|c|c|c|c|c|c|}
\hline $\begin{array}{l}\text { Cover type } \\
\text { category }\end{array}$ & Plot name & Cover type & $\begin{array}{l}\text { Major vegetation species occurring in } \\
\text { cover type }\end{array}$ & Training site area & $\begin{array}{l}\text { Number } \\
\text { of pixels }\end{array}$ \\
\hline $\begin{array}{l}\text { Sagebrush } \\
\text { shrubland }\end{array}$ & sage1 & sagebrush and grass & Artemisia tridentata, Festuca idahoensis & Mammoth (Line 2) & 216 \\
\hline $\begin{array}{l}\text { Sagebrush } \\
\text { shrubland }\end{array}$ & sage2 & sagebrush and grass & Artemisia tridentata, Festuca idahoensis & Mammoth (Line 2) & 81 \\
\hline $\begin{array}{l}\text { Sagebrush } \\
\text { steppe }\end{array}$ & sage/fescue1 & mixed sage and grass & $\begin{array}{l}\text { Artemisia tridentata, Festuca idahoensis, } \\
\text { Geranium viscosissimum }\end{array}$ & Lamar Valley (Line 4) & 129 \\
\hline $\begin{array}{l}\text { Sagebrush } \\
\text { steppe }\end{array}$ & sage/fescue2 & $\begin{array}{l}\text { mixed sage and grass on } \\
\text { north-facing slope }\end{array}$ & $\begin{array}{l}\text { Artemisia tridentata, Festuca idahoensis, } \\
\text { Geranium viscosissimum }\end{array}$ & Lamar Valley (Line 4) & 51 \\
\hline Grassland & fescue/wheatgrass 1 & $\begin{array}{l}\text { mixed Idaho fescue and } \\
\text { bearded wheatgrass - wet phase }\end{array}$ & $\begin{array}{l}\text { Festuca idahoensis, Agropyron caninum, } \\
\text { Geranium viscosissimum }\end{array}$ & Lamar Valley (Line 4) & 62 \\
\hline Grassland & fescue/wheatgrass 2 & $\begin{array}{l}\text { mixed Idaho fescue and } \\
\text { bearded wheatgrass - dry phase }\end{array}$ & Festuca idahoensis, Agropyron caninum & Lamar Valley (Line 4) & 56 \\
\hline Grassland & fescue/wheatgrass 3 & $\begin{array}{l}\text { mixed Idaho fescue and } \\
\text { bluebunch wheatgrass }\end{array}$ & Festuca idahoensis, Agropyron spicatum & Lamar Valley (Line 4) & 78 \\
\hline Grassland & fescue/needlegrass & $\begin{array}{l}\text { mixed Idaho fescue } \\
\text { and Richardson's needlegrass }\end{array}$ & Festuca idahoensis, Stipa richardsonii & Lamar Valley (Line 4) & 510 \\
\hline Grassland & bromus & Smooth brome & Bromus inermis & Lamar Valley (Line 4) & 65 \\
\hline Wet nonforest & willow/sedge & willow and sedge & Salix sp., Carex sp. & Norris (Line 2) & 39 \\
\hline Wet nonforest & willow & willow & Salix sp. & Norris (Line 2) & 30 \\
\hline Wet nonforest & sedge & sedge & Carex sp. & Mammoth (Line 2) & 183 \\
\hline Wet nonforest & cattail & cattails & Typha sp. & Old Faithful (Line 1) & 18 \\
\hline Wet nonforest & wetland1 & Mixed wetland & Mixed wetland vegetation & Old Faithful (Line 1) & 11 \\
\hline Wet nonforest & wetland 2 & Mixed wetland & Mixed wetland vegetation & Mammoth (Line 2) & 53 \\
\hline
\end{tabular}

continuum slope constraints and other methods (Clark et al., in press (a).

For the comparison of the entries of a spectral library to the spectrum of an AVIRIS pixel using only a single absorption feature, the fit values calculated between the library entries and the pixel are compared and the entry with highest fit value is selected as the best match. In Tetracorder, multiple absorption features in a single material (i.e., library entry) are used with a list of user-specified constraints to select the best match (Clark et al., in press (a). A standard constraint in the applications of Tetracorder has been the definition of a minimum continuum threshold level. Deeply shadowed pixels have low reflectance (e.g., pixels along the north-facing slope of a canyon). Such pixels have a low signal-to-noise ratio, making it difficult to discern absorption features through the noise. In Tetracorder, a minimum threshold level of $4 \%$ reflectance was set for the midpoint of the continua for all entries in the Yellowstone vegetation spectral library. For pixels with a continuum reflectance level below this threshold, Tetracorder will not attempt to determine the vegetation cover type. Despite the many other refinements available in Tetracorder, such as constraints on feature depth, fit, and continuum slope, in this study we did not employ tight constraints, preferring instead to see how the spectral feature fitting selected the best matches.

In this application of Tetracorder to the vegetation in Yellowstone, we selected three absorption features to use in the comparison of AVIRIS data to the spectral library: the chlorophyll absorption feature at $0.68 \mu \mathrm{m}$, and the 0.98 and
$1.20 \mu \mathrm{m}$ leaf water absorption features. The continuum endpoints were defined as a range of wavelengths (Table 3 ). In the computation of the continuum line, the AVIRIS channels within each range were averaged in order to reduce the effect of noise in the computations.

In this study, the fit values for the chlorophyll and two water absorption features were weighted by approximately $0.70,0.15$, and 0.15 , respectively, and added together.

$r_{\text {total }}=w_{1} r_{1}+w_{2} r_{2}+w_{3} r_{3}$

These weights $\left(w_{1} \sim 0.70, w_{2} \sim 0.15, w_{3} \sim 0.15\right)$ were approximate because the Tetracorder system does not currently allow the weights to be set by the user. Normally, the weights are determined by the area of each continuum removed feature relative to the total area of all features. To achieve the approximate weights, the water absorption

Table 3

Continuum endpoints used for vegetation absorption features

\begin{tabular}{llll}
\hline Cover type & Absorption feature & $\begin{array}{l}\text { Left continuum } \\
\text { range }(\mu \mathrm{m})\end{array}$ & $\begin{array}{l}\text { Right continuum } \\
\text { range }(\mu \mathrm{m})\end{array}$ \\
\hline Forest & Chlorophyll $(0.68 \mu \mathrm{m})$ & $0.512-0.542$ & $0.737-0.767$ \\
& Water $(0.98 \mu \mathrm{m})$ & $0.870-0.900$ & $1.055-1.085$ \\
& Water $(1.20 \mu \mathrm{m})$ & $1.083-1.113$ & $1.270-1.300$ \\
Nonforest & Chlorophyll $(0.68 \mu \mathrm{m})$ & $0.512-0.542$ & $0.737-0.767$ \\
& Water $(0.98 \mu \mathrm{m})$ & $0.895-0.925$ & $1.055-1.085$ \\
& Water $(1.20 \mu \mathrm{m})$ & $1.083-1.113$ & $1.270-1.300$ \\
\hline
\end{tabular}


features were listed multiple times, as necessary, for each reference spectrum. Thus, for a pixel of AVIRIS data, a total weighted-fit value was calculated for each entry in the spectral library. Subsequently, the "best match" of the AVIRIS pixel to the spectral library was selected as the entry with the highest total weighted-fit value. For each entry in the spectral library, a raster image was produced by assigning the fit value to the pixels for which the cover type was selected as the best spectral match (all other pixels were set to zero). The pixel values are an indication of the closeness of the match between the pixel spectrum and the library spectrum. Thus, the range in values of the pixels may be viewed as the degree of confidence in the match and the image may be processed with simple contrast stretching to represent the full range of fit values or only the relatively high fit values. By selecting different colors for each cover type, fit images were combined into thematic maps of conifer and nonforest cover.

\section{Results and discussion}

\subsection{Spectra of vegetation cover types}

This section presents the reflectance spectra and continuum removed absorption features of the vegetation cover types in Yellowstone. For clarity, in the following plots, only a single representative spectrum from each forest cover type (listed in Table 1) is presented. In the figures of reflectance spectra, the mean spectrum of the training site is shown along with \pm 1 standard deviation from the mean.

\subsubsection{Reflectance spectra}

Reflectance spectra of the forest cover types are shown in Fig. 5a-b. The nonforest vegetation cover types listed in Table 2 were divided into three groups for clarity. The first group, the "wet" nonforest vegetation, contains the relatively lush nonforest vegetation that contained a significant amount of chlorophyll and water in the leaves. The second group, "grasslands," contains the vegetation cover types dominated by graminoid species. The final group includes "sagebrush shrublands" and "sagebrush steppes", which represent those cover types with a significant amount of sagebrush in addition to grasses. The spectra of these wet nonforest, grassland, and sagebrush cover types are shown in Fig. $5 \mathrm{c}-\mathrm{e}$, respectively.

In general, the conifer reflectance spectra in Fig. 5a have a low level of reflectance (less than 5\%) in the visible region and a maximum reflectance level of $15-24 \%$ at $1.1 \mu \mathrm{m}$ in the NIR plateau. The reflectance spectra of lodgepole pine age classes presented in Fig. 5b show a change in the NIR plateau $(0.75-1.30 \mu \mathrm{m})$ from young to old stands. The spectrum of the LP0 age class, consisting of young lodgepole pine seedlings, shows the NIR-plateau region to have weak leaf water absorption features superimposed on a generally positive slope. In contrast, the LP3 stand has strong leaf water absorption features at $0.98,1.20$, and $1.40 \mu \mathrm{m}$. The LP3 lodgepole pine stand has a broken overstory that is beginning to be replaced by a mixed spruce/fir overstory (Despain, 1990). As a result, the ragged canopies of LP3 have gaps in the overstory. The increased strength of the water absorption features may arise from multi-scattering in this variable height canopy and/or from higher water content in the understory vegetation.

The wet nonforest cover types have much higher reflectance in the NIR plateau (see Fig. 5c) compared to the forest cover (Fig. 5a). These cover types have reflectance from $30 \%$ to $50 \%$ at $1.1 \mu \mathrm{m}$. The leading edge $(0.75-0.90 \mu \mathrm{m})$ of the NIR plateau shows some variation in slope from a steep slope for the sedge spectrum to a near-zero slope for the wetland 1 spectrum. The reflectance spectra of the grassland cover types in Fig. 5d show a range in spectral features. The variations are dependent on the moisture regime in which the different cover types grow. Fescue/wheatgrass 1 is located in a moisture-rich area. This is reflected in the strong chlorophyll and water absorption features in its spectrum. In contrast, fescue/wheatgrass 2 , a drier phase of the fescue/wheatgrass 1 , shows the water features to be weaker and the 2.10 and $2.30 \mu \mathrm{m}$ absorption features are revealed.

The reflectance of sagebrush cover types (Fig. 5e) differ greatly from the forest and lush vegetation. These plants grow in sparse groups and had low water content at the time of the overflight (August, 1996). Thus, the reflectance spectra of sagebrush cover types show weaker absorption due to water, which reveal the longer wavelength absorption features at 2.10 and $2.30 \mu \mathrm{m}$ that arise from leaf biochemical constituents (e.g., lignin and cellulose). Sagebrush leaves are covered by fine hairs, which have a primary composition of cellulose. These plant materials and the many woody stems of the shrub contribute to the strengths of the longer wavelength absorption features at 2.10 and $2.30 \mu \mathrm{m}$ in the spectra of sagebrush. Furthermore, the spectra show weak absorption at the $0.68 \mu \mathrm{m}$ chlorophyll position because the sagebrush plants have relatively low chlorophyll content and most grasses in these areas were senescent at the time of the AVIRIS overflight.

\subsubsection{Continuum removed absorption features}

Continuum removal applied to the chlorophyll absorption feature of the forest spectra (Fig. 6a) reveals that the pines have weaker absorption strengths compared to the other conifers, with lodgepole pine having the weakest chlorophyll absorption. Douglas fir has the strongest absorption feature. In Fig. 6b, the age classes of lodgepole pine show increasing band depth from the youngest class, LP0, to LP1, LP2, and finally, LP3. The depth of the chlorophyll absorption in these remotely sensed canopy spectra is due to both the concentration of chlorophyll in the needles and the percent cover of the vegetation over the background rock and soil. Compared to the more 

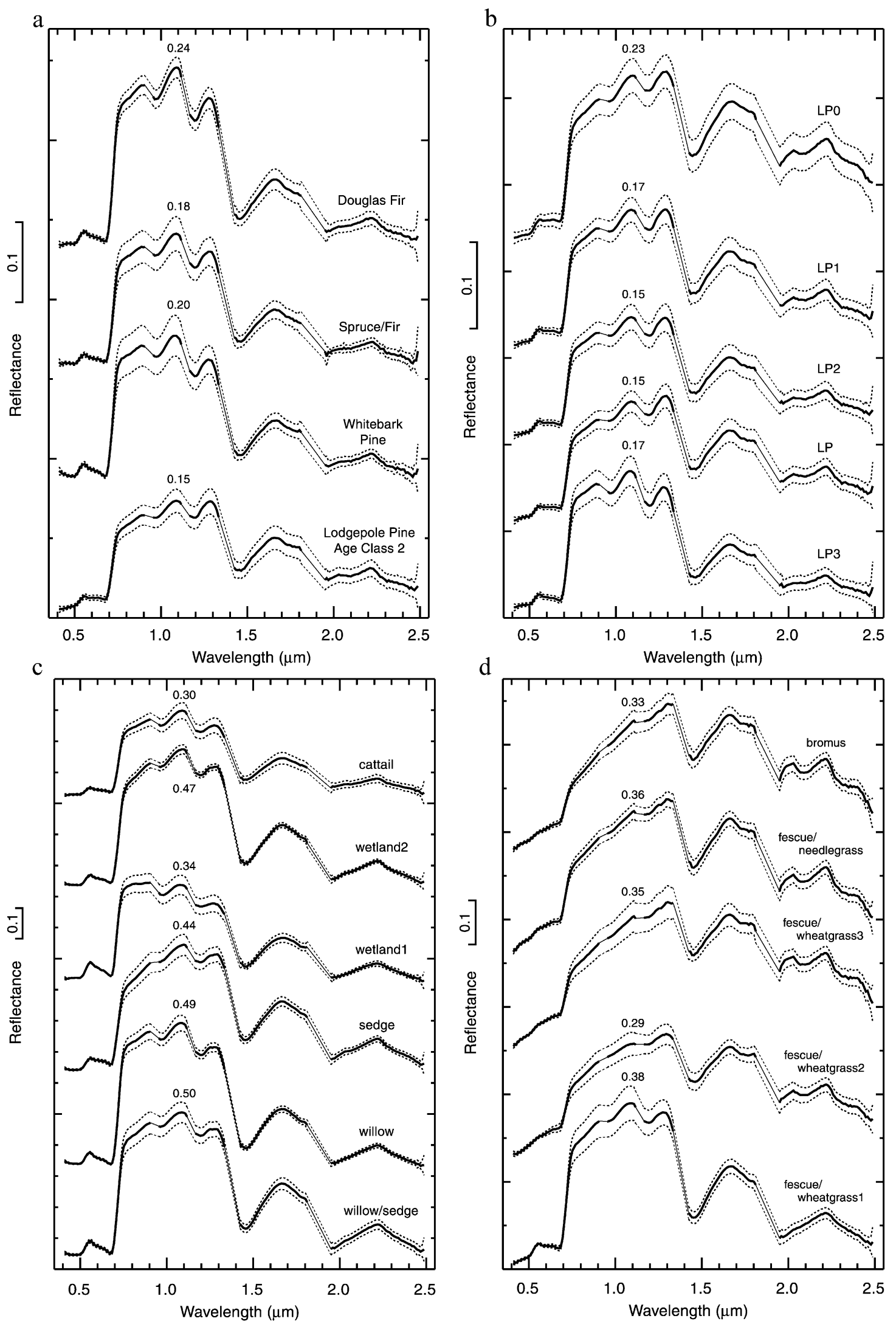


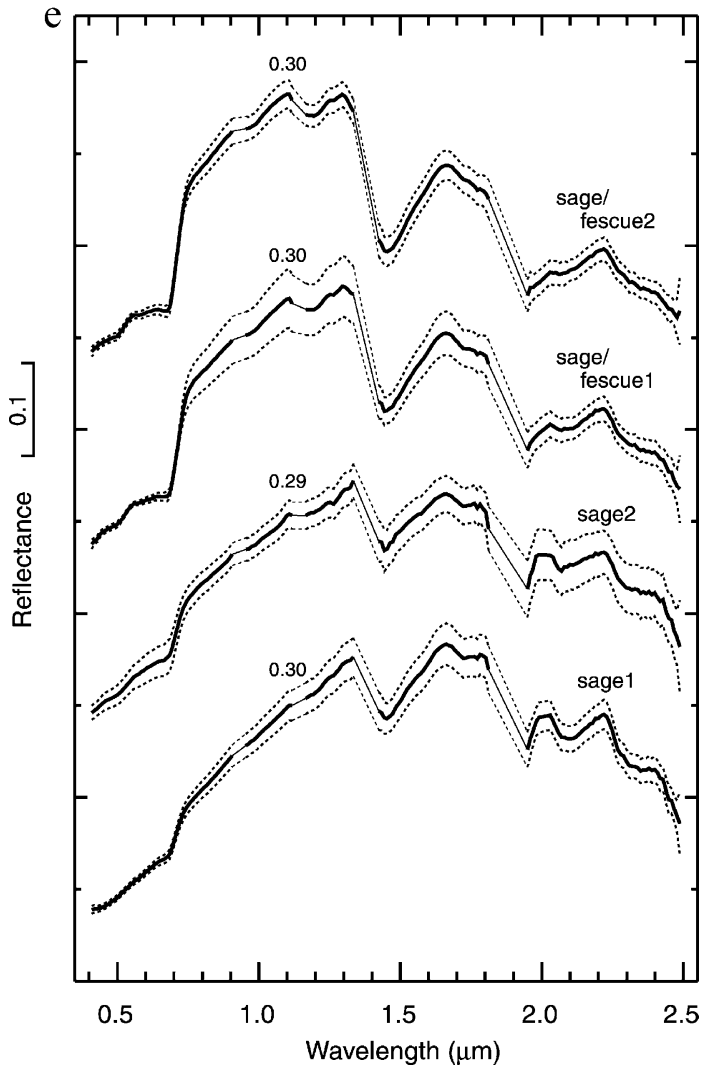

Fig. 5. Representative AVIRIS RTGC mean reflectance spectra (solid lines) with \pm 1 standard deviation (dotted lines) of the training sites for Yellowstone vegetation: (a) conifer cover types, spectra are plotted at fixed intervals of 0.1 but offset by 0.15 ; (b) lodgepole pine age classes (see Despain, 1990), spectra are plotted at fixed intervals of 0.1 but offset by 0.10 ; (c) lush nonforest vegetation, spectra are plotted at fixed intervals of 0.1 but offset by 0.30 ; (d) grassland cover types, spectra are plotted at fixed intervals of 0.1 but offset by 0.23 ; (e) sagebrush cover types, spectra are plotted at fixed intervals of 0.1 but offset by 0.22 . Reflectance values of the mean spectra at $1.1 \mu \mathrm{m}$ are given in the figures. Wavelength regions of deleted channels are represented by the thin lines.

homogenous LP1 and LP2 canopies, the LP3 cover type has a variable height canopy with mature conifers in the overstory and younger subalpine-fir and Engelmann spruce in the understory. Such differences in canopy structure can affect the multiple scattering of light in the canopy (Kimes, 1983). This suggests that multiple scattering effects might have an impact on the apparent strength of the chlorophyll absorption (Salisbury, Milton, \& Walsh, 1987). The LP1, LP2, and LP age classes all show similar shapes of the chlorophyll absorption feature. Because of the similarities between LP1, LP2 and LP spectra, these age classes of lodgepole pine may be difficult to distinguish from one another spectrally based only on the chlorophyll absorption feature.

In general, the continuum removed chlorophyll absorption features of the lush nonforest vegetation were stronger in comparison to the other cover types. Within this group, there is considerable variation in the shapes of the feature. This is likely caused by relative differences in concentra- tions of pigments between the cover types. At the time of the overflight, the leaves of the nonforest plants in Yellowstone were in various stages of senescence.

With the exception of fescue/wheatgrass1, all the grassland training sites had weak chlorophyll features. The fescue/wheatgrass 1 site contains a wet phase of the Idaho fescue/bearded wheatgrass grassland and the stronger chlorophyll feature is consistent with this site retaining its chlorophyll later in the season because of available water in comparison to the other grasslands. The spectra of the mixed sage/grassland sites (sage/fescue1 and sage/fescue2) showed stronger chlorophyll absorption features compared to the sagebrush shrublands (sage1 and sage2).

The continuum removed $0.98 \mu \mathrm{m}$ water absorption feature is shown for the different forest training sites in Fig. 7a. In contrast to the chlorophyll absorption feature, this feature shows that whitebark pine has stronger absorption than the mixed Engelmann spruce/subalpine fir forest. Fig. $7 \mathrm{~b}$ shows that the LP1 and LP2 absorption features are extremely similar. Of the lodgepole pine age classes, LP3

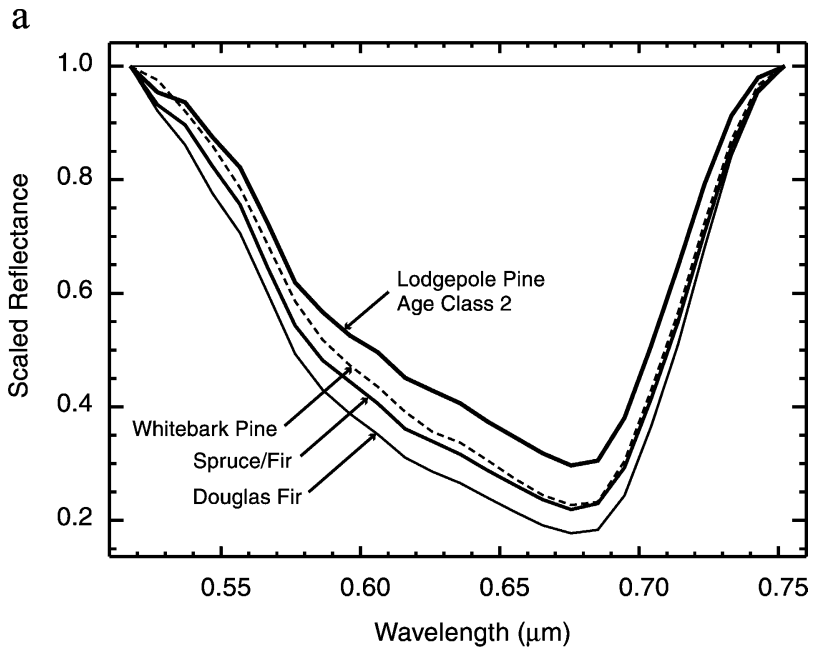

b

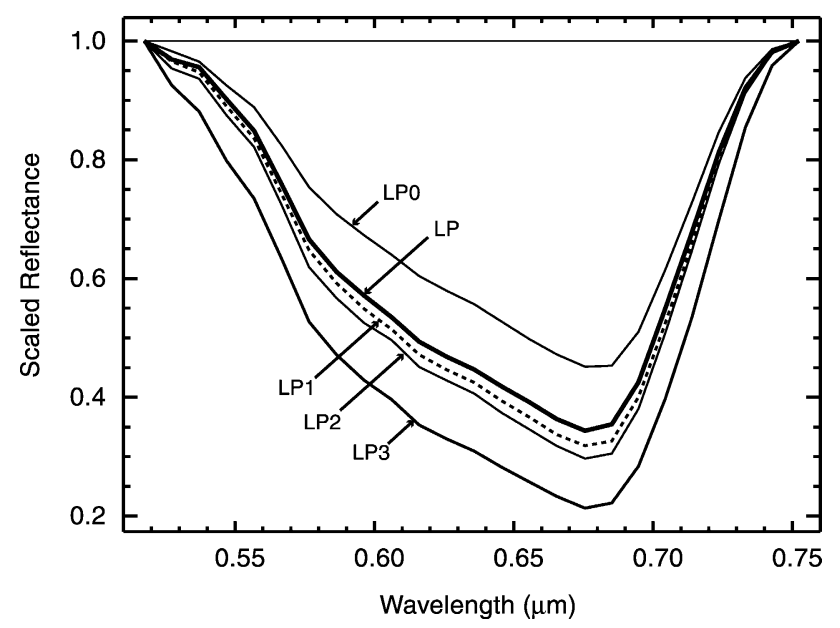

Fig. 6. Continuum removed $0.68 \mu \mathrm{m}$ chlorophyll absorption feature for: (a) conifer cover types, (b) lodgepole pine age classes LP0-3, LP. 
a

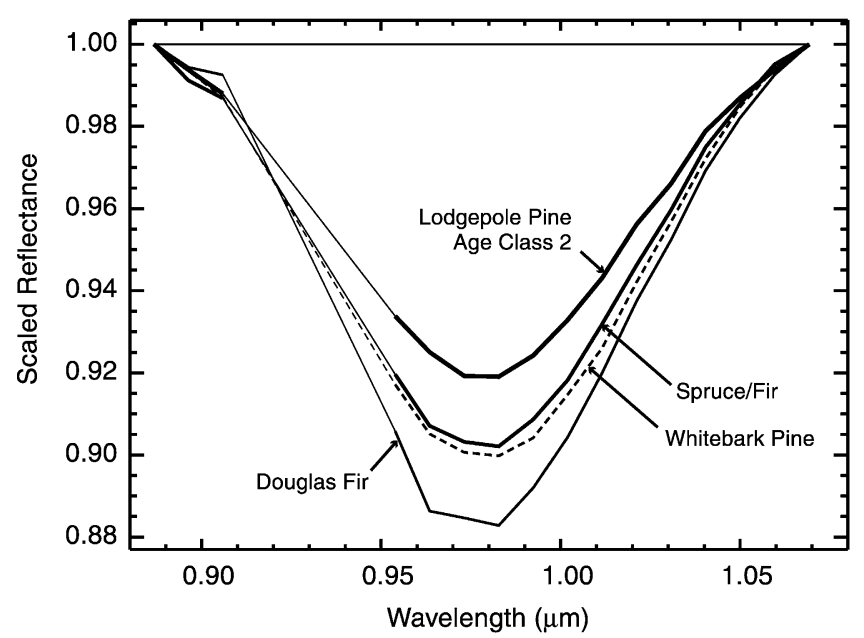

C

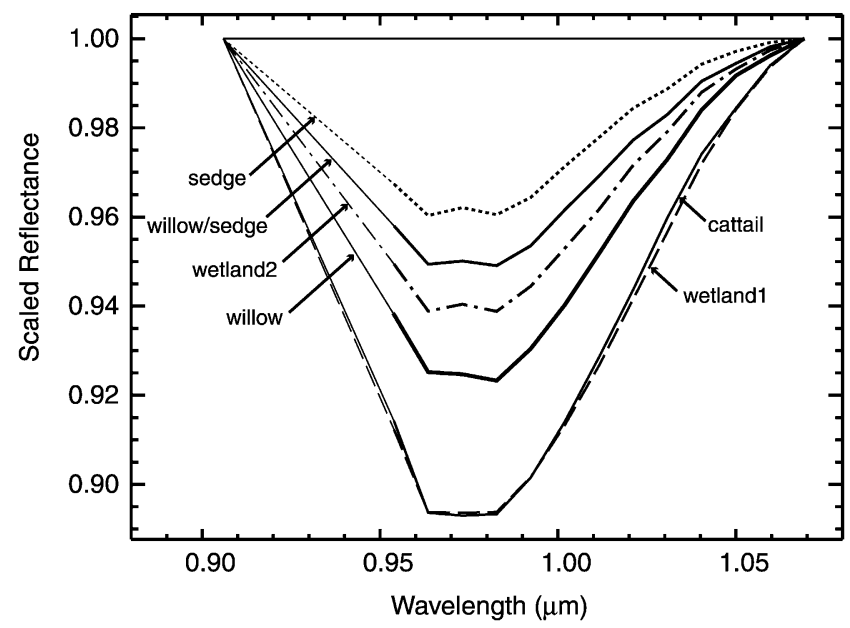

b

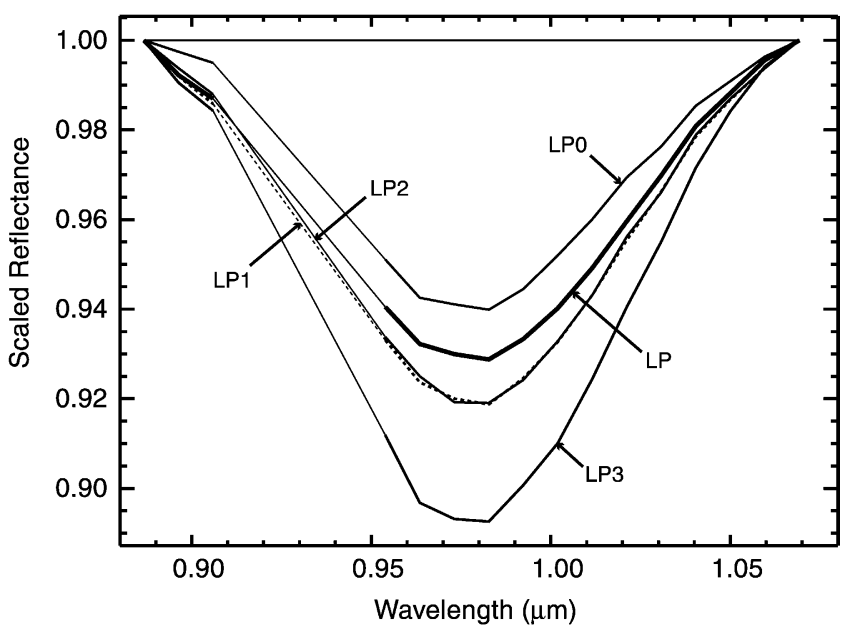

d

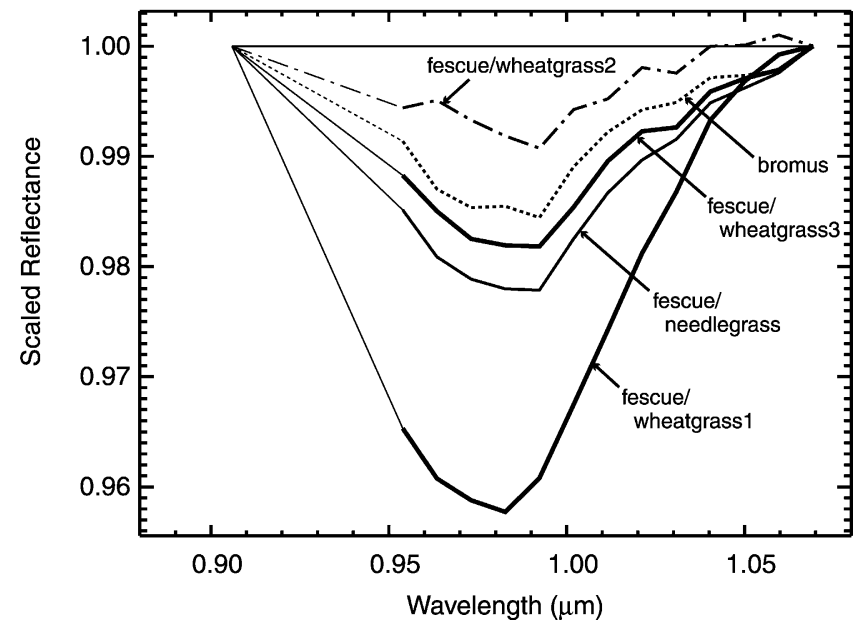

Fig. 7. Continuum removed $0.98 \mu \mathrm{m}$ leaf water absorption feature for: (a) conifer cover types; (b) lodgepole pine age classes, LP0-3, LP; (c) lush nonforest vegetation; (d) grassland cover types. Wavelength regions of deleted channels are represented by the thin lines.

had the strongest water absorption at $0.98 \mu \mathrm{m}$. LP0 had the weakest absorption feature.

Fig. 7c shows the $0.98 \mu \mathrm{m}$ absorption feature due to leaf water in the lush nonforest vegetation types. The most distinguishing element of the shapes of these features compared to other cover types is the broad, flat bottom of the feature. The features here are flat from approximately 0.962 to $0.982 \mu \mathrm{m}$. In contrast, the forest vegetation show a narrow feature with a distinct band minimum at $0.982 \mu \mathrm{m}$ (Fig. 7a-b).

The $0.98 \mu \mathrm{m}$ water absorption features are weak for the grassland cover types (Fig. 7d), again with the exception of the fescue/wheatgrass 1 site. This absorption feature in the spectra of the sagebrush sites is also weak with depths of $3.5 \%$ or less. The absorption features for the sagebrush shrublands (sage1 and sage 2$)$ are extremely weak $(<2 \%$ band depth) and as a result noise affects the shape of the absorption feature. The same trends, for all cover types, were evident in the $1.20 \mu \mathrm{m}$ leaf water absorption feature.

\subsubsection{Spectral variability of cover types}

The mean spectra of the cover types are plotted with \pm 1 standard deviation in Fig. 5. This gives some sense of the variability in reflectance for the pixels of the training sites. The Tetracorder expert system used in this study, which discriminates between materials based on their spectral shapes, will have the greatest difficulty distinguishing between cover types that have similar spectral features. For pixels in the training sites with similar mean spectra, high variability of spectra will also make consistent discrimination more challenging. A plot of the means and standard deviations of the continuum removed features represent the overall levels of variation. However, for spectral feature analysis methods, the differences in spectral shape hold the discriminating power. Thus, changes in the vector or trajectory of the continuum removed spectra, between two vegetation types (as shown in Fig. 4c), have greater impact on spectral identification compared to simple consistent variations in the depth of a feature. 
The spectra of all pixels in the training sites were compared to the spectral library of Yellowstone vegetation types using Tetracorder. The results of the Tetracorder identifications were evaluated at three levels: (1) matches to the library entry for the mean spectrum of the training site from which the pixel came, (2) matches to library entries in the same general cover type (e.g., selection of any of the three Douglas fir entries in the spectral library as the best match to a pixel from a Douglas fir training site), and (3) matches to forest vs. nonforest entries in the spectral library. Table 4 summarizes the percentage of correct identifications at these three levels.

Pixels from the training sites of whitebark pine, Douglas fir, and spruce/fir had similar levels of matches to their mean spectra, $67.6 \%, 70.0 \%$, and $73.8 \%$, respectively. Pixels in the LP1, LP2, and LP3 cover types had the lowest degree of match to their respective means ( $40-49 \%$ match, column three of Table 4). As discussed previously, the absorption features of LP1 and LP2 have similar spectral shape. The pixels of LP1 that did not match the mean spectrum tended to match LP2 (24.2\%) and LP (19.5\%). The pixels of LP2 that did not match their mean spectrum were closer matches to the reflectance spectra of LP1 (22.4\%) and LP (26.4\%). Additional research is needed to determine whether other descriptors of the spectra of these cover types might be used to better discriminate these age classes. For example, the mean spectrum of the LP cover type has more shallow chlorophyll and water absorption features. The addition of thresholds on the depths of these features and continuum slopes might improve identifications. Furthermore, the definition of training sites for the lodgepole pine age classes might be improved by studies relating ground observations of tree height, crown size, and canopy closure to AVIRIS spectra. The links between the aging of stands of lodgepole pine, the canopy structural changes, understory variations, and reflectance spectra need to be investigated.

The pixels of the LP3 class showed a match of $43.2 \%$ with their mean. The second highest match was to the Engelmann spruce/subalpine fir (SF) cover type (28.8\%). LP3 represents an intermediate stage between lodgepole pine dominated forests and climax SF forests. As a result, definition of a mean spectrum for this mixed category is complicated. Within an area designated as LP3, the dominant cover shifts between LP2 and SF (Despain, 1990). Column 4 of Table 4 demonstrates that the pixels of the LP3 age class match a mean spectrum of one of the lodgepole pine spectra in the general lodgepole pine category at a level of $55.3 \%$. In contrast, the individual pixels from the other lodgepole pine age classes match the general lodgepole pine category very well $(98-100 \%)$.

For nonforest cover, comparing the spectra of individual pixels to the mean spectra revealed that a higher overall match to their mean spectra $(74.7 \%$, column 3 of Table 5$)$ than that obtained for the forest cover types $(67.9 \%$, column 3 of Table 4). The lowest individual degree of correspondence was $59.3 \%$ for the sage 1 cover type. The pixels of the sage1 training site matched the mean spectra of grassland cover types $37 \%$ of the time. The results show that designation of a representative spectrum for this area could be improved.

The overall match of individual pixels of nonforest cover to their general categories was $85.8 \%$. The overall match of individual pixels of forest training sites to their general forest categories was even greater, showing an overall $91 \%$ success. Tables 4 and 5 also show that there is little misidentification of pixels from forest sites as matching the mean spectrum of a nonforest cover type $(0.1 \%)$. Similarly, a low fraction (1.7\%) of pixels from nonforest cover type training sites was identified as matching a mean spectrum of a forest cover type.

\subsection{Maps of vegetation cover derived from AVIRIS data}

\subsubsection{Forest cover}

Forest cover maps for Yellowstone were produced by applying the USGS Tetracorder expert system to the calibrated AVIRIS data using the image-derived spectral library of vegetation. In this paper, we focus on two specific areas of the park for discussion: Mount Washburn and Mammoth Hot Springs. The map of forest cover for the Mount Washburn area of Yellowstone is presented in Fig. 8. In

Table 4

Results of spectral comparisons between the reflectance of individual pixels and the mean reflectance spectrum for forest vegetation types

\begin{tabular}{|c|c|c|c|c|}
\hline Specific forest cover type & $\begin{array}{l}\text { General forest } \\
\text { category }\end{array}$ & Exact match $(\%)$ & $\begin{array}{l}\text { General forest } \\
\text { category match (\%) }\end{array}$ & Forest match $(\%)$ \\
\hline Lodgepole pine age class 0 & Lodgepole pine & 93.0 & 100.0 & 100 \\
\hline Lodgepole pine age class 1 & Lodgepole pine & 40.3 & 99.2 & 100 \\
\hline Lodgepole pine age class 2 & Lodgepole pine & 49.2 & 98.4 & 100 \\
\hline Lodgepole pine age class 3 & Lodgepole pine & 43.2 & 55.3 & 100 \\
\hline Lodgepole pine climax stage & Lodgepole pine & 63.5 & 98.0 & 99.3 \\
\hline Whitebark pine & Whitebark pine & 67.6 & 85.3 & 100 \\
\hline Spruce/fir & Spruce/fir & 70.0 & 70.0 & 100 \\
\hline Douglas fir & Douglas fir & 73.8 & 78.6 & 100 \\
\hline Overall & & 67.9 & 91.0 & 99.9 \\
\hline
\end{tabular}


Table 5

Results of spectral comparisons between the reflectance of individual pixels and the mean reflectance spectrum for nonforest vegetation types

\begin{tabular}{|c|c|c|c|c|}
\hline $\begin{array}{l}\text { Nonforest cover } \\
\text { type reference }\end{array}$ & General nonforest category & Exact match $(\%)$ & $\begin{array}{l}\text { General nonforest } \\
\text { category match }(\%)\end{array}$ & Nonforest match $(\%)$ \\
\hline Sage 1 & Sagebrush shrubland & 59.3 & 64.8 & 99.1 \\
\hline Sage2 & Sagebrush shrubland & 87.7 & 93.8 & 100 \\
\hline Sage/fescue1 & Sagebrush steppe & 62.0 & 69.8 & 97.7 \\
\hline Sage/fescue2 & Sagebrush steppe & 100 & 100 & 100 \\
\hline Fescue/wheatgrass 1 & Grassland & 96.8 & 96.8 & 96.8 \\
\hline Fescue/wheatgrass2 & Grassland & 92.9 & 96.4 & 96.4 \\
\hline Fescue/wheatgrass3 & Grassland & 79.5 & 93.6 & 100 \\
\hline Fescue/needlegrass & Grassland & 65.9 & 86.7 & 99.8 \\
\hline Bromus & Grassland & 76.9 & 87.7 & 100 \\
\hline Willow/sedge & Wet nonforest & 94.9 & 97.4 & 97.4 \\
\hline Willow & Wet nonforest & 73.3 & 73.3 & 73.3 \\
\hline Sedge & Wet nonforest & 83.6 & 95.1 & 96.7 \\
\hline Cattail & Wet nonforest & 88.9 & 88.9 & 88.9 \\
\hline Wetland1 & Wet nonforest & 98.1 & 100 & 100 \\
\hline Wetland2 & Wet nonforest & 100 & 100 & 100 \\
\hline Overall & & 74.7 & 85.8 & 98.3 \\
\hline
\end{tabular}

this figure, the colored pixels representing the different forest cover types are overlaid on a grayscale background image. Thus, the pixels in this figure that do not have forest cover are depicted in the grayscale. In general, white pixels are bare ground, grey pixels are grasslands or other nonforest vegetation, and black pixels are areas of water or deep shadows.

The forest cover map for Mount Washburn (Fig. 8) shows that the scene is dominated by a cover of lodgepole pine. In the image, the lodgepole pine age classes (LP1, LP2, LP, and LP3) were grouped together in order to more clearly show the distributions of the different conifer species. The noticeable features of the image are that Douglas fir (DF) was found to dominate the forest cover within the Grand Canyon of the Yellowstone and that whitebark pine (WB) was mapped in high concentrations on the upper slopes of Mount Washburn. The mixed Engelmann spruce/ subalpine fir category (SF) was found to be distributed on the southern slopes of Mount Washburn, but at lower elevations than WB and not in such solid concentrations as the other forest cover types. The occurrences of WB along the trail from Dunraven Pass to the summit of Mount Washburn were confirmed by field survey. The distribution of $\mathrm{WB}$ in the image agrees with the expected elevation ranges of these forests, above $2600 \mathrm{~m}$ (Despain, 1990). In the entire AVIRIS data set for Yellowstone, whitebark pine was rarely mapped by the Tetracorder system at lower elevations.

The distributions of forest cover types in the Mount Washburn scene were compared to existing maps compiled from air photos (Despain, 1990). Table 6 shows the results of an accuracy assessment performed using ERDAS Imagine software. The overall accuracy was $74.1 \%$. The kappa statistic (Cohen, 1960) was computed at 0.62. The kappa statistic, introduced to remote sensing in order to compare the results produced by different air photo interpreters
(Congalton \& Mead, 1983), has been viewed as a standardized way to report a "chance-corrected" measure of agreement. However, even in the case of a simplified binary classification, the reliability of this statistic, and the appropriateness of its use as a standard, have been questioned (Byrt, Bishop, \& Carlin, 1993). Despite these issues, both the overall accuracy and the kappa statistic show good agreement between these maps, certainly when considering that the analysis methods applied to the two sources of remote sensing data were quite different. In contrast to the spectral comparison methods used here, the air photo interpretation involved classifying the texture of the forest cover (including crown shapes, sizes and shadowing). Differences between the images are also expected to arise from errors in georeferencing and changes related to the time differences of the imagery (1968-1972 for the air photos and 1996 for the AVIRIS), such as changes in forests due to fire, disease, and other disturbances.

A comparison of the AVIRIS mapping results to air photos revealed that the pixel-by-pixel nature of the spectral analysis methods showed considerably greater short distance variation in forest cover. It is possible that the AVIRIS results could be subject to additional analysis of a contextual nature by considering the identification of the cover type of a pixel in relation to its neighbors. A simple neighborhood analysis was performed, using a $3 \times 3$ cell size to assign each pixel to the cover type of the majority surrounding that cell. The resulting maps had the short period variations greatly reduced and did appear more like the map derived from air photos. However, even without such refinement, the polygons drawn for different forest stands from the air photos generally matched the distributions in Fig. 8. The most significant difference was noted on the southern slopes of Mount Washburn where the texture analysis of air photos by Despain (1990) delineated large polygons of LP3 and the spectral analysis of AVIRIS data revealed a variable pattern 


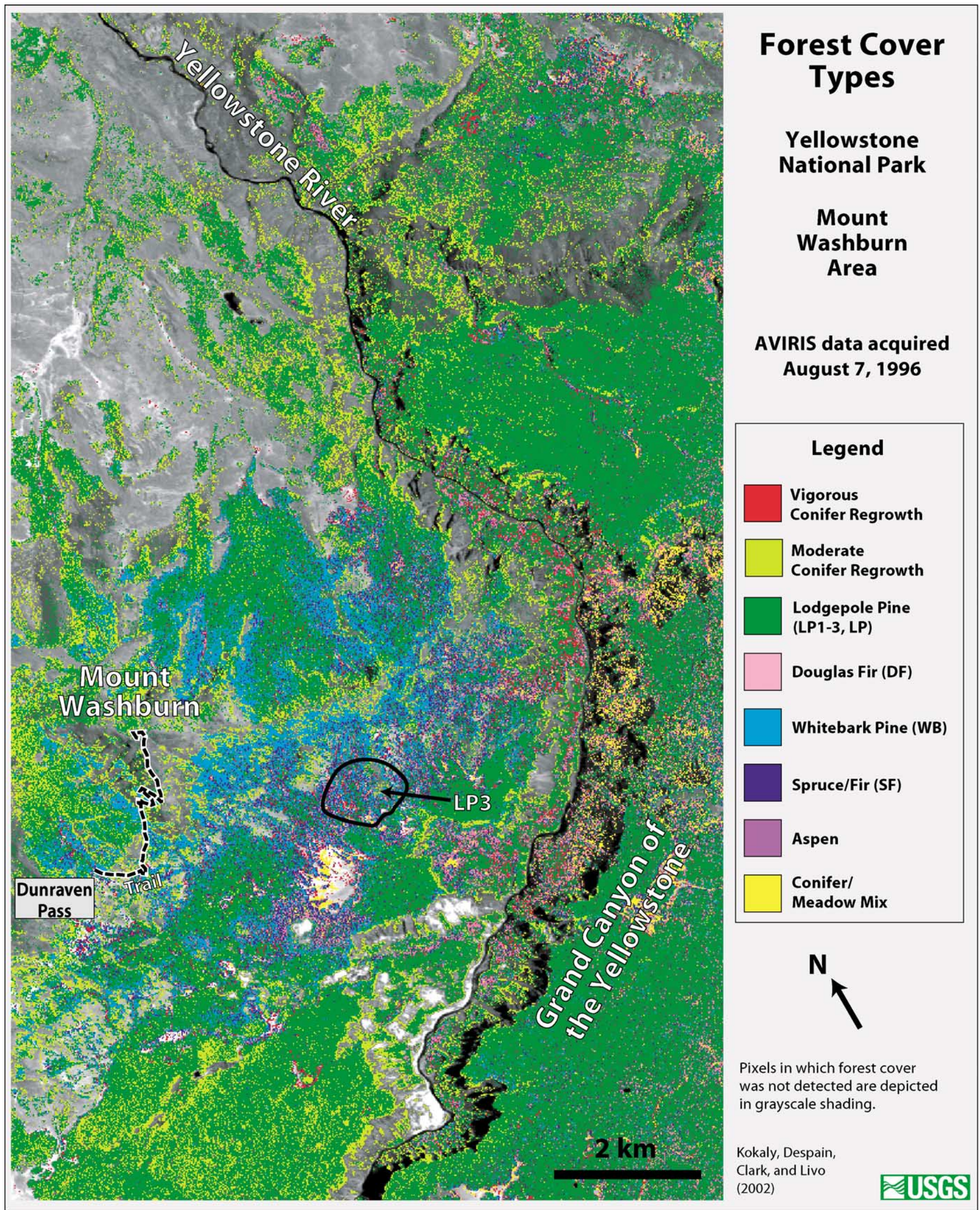

Fig. 8. Map of forest cover types for the Mount Washburn area of Yellowstone National Park derived from AVIRIS data and the USGS Tetracorder expert system. The approximate location of the trail from Dunraven pass to the peak of Mount Washburn is indicated by the dashed line. 
Table 6

Confusion matrix and agreement assessment between AVIRIS and air photo forest maps

\begin{tabular}{|c|c|c|c|c|c|c|}
\hline \multirow[t]{2}{*}{ AVIRIS identification } & \multicolumn{4}{|c|}{ Air photo classification } & \multirow{2}{*}{$\begin{array}{l}\text { User's } \\
\text { accuracy (\%) }\end{array}$} & \multirow{2}{*}{$\begin{array}{l}\text { Producer's } \\
\text { accuracy }(\%)\end{array}$} \\
\hline & Lodgepole pine & Whitebark pine & Spruce/fir & Douglas fir & & \\
\hline Lodgepole pine & 82 & 2 & 0 & 4 & 93.2 & 66.7 \\
\hline Whitebark pine & 21 & 40 & 0 & 1 & 64.5 & 81.6 \\
\hline Spruce/fir & 8 & 6 & 18 & 3 & 51.4 & 100.0 \\
\hline Douglas fir & 12 & 1 & 0 & 26 & 66.7 & 76.5 \\
\hline \multicolumn{7}{|l|}{ Overall accuracy $=74.1 \%$} \\
\hline
\end{tabular}

of LP, SF, and WB cover types in these areas (an example of such an area is circled in Fig. 8). Considering the description of the LP3 cover type in Despain (1990) as a mix of these three cover types, the results of the AVIRIS mapping are showing the same spatial patterns depicted by the air photo interpretations.

A close examination of the AVIRIS map of forest cover in the Mount Washburn area revealed some possible errors in the mapping. Occasionally, along the edges of forest stands, a line of pixels occurs that are of a different type than the main body of the stand. For example, the edges of forest stands in some areas were identified as LP0 (moderate lodgepole pine regrowth) while older lodgepole pine was mapped in the main body of the forest stand. For some areas this may represent forest encroachment into meadows; however, another cause for these edge features may be mixing effects between the forest and nonforest vegetation that lead to a spectral misidentification. This misidentification can be predicted, to some extent, by the types of vegetation that are present in the main body of the forest stand and the nonforest vegetation on its border. For example, LP1 cover mixed with a dry grassland would weaken the chlorophyll absorption in the spectrum toward the shallower absorption of LP0 (see Fig. 6b). The LP0 training site was an area of small lodgepole pine seedlings in a grass matrix. Thus, the effect of LP1 thinning into a grass meadow would be expected to have similar reflectance to the LP0 training site. Pixels at the edge of the same LP1 forest but bordering on a wet meadow would have increased water absorption and may be more spectrally similar to DF or SF. Some type of spectral mixture modeling may assist the spectral feature analysis approach used in this study; however, an adequate solution to this effect presents a challenge because the nature of this mixing may be both linear and nonlinear.

The map generated for the Mount Washburn area can be used to assist in examining other parts of the Yellowstone geo-ecosystem. Whitebark pine was mapped along the slopes of Mount Washburn in areas where grizzly bears forage for food. The link between whitebark pine and grizzly bears is provided by red squirrels which store cones from the trees in middens; these middens are raided by grizzly bears (Mattson \& Reinhart, 1997; Mattson et al., 1992). The more homogeneous stands of whitebark pine may be more or less preferred habitat than areas where whitebark occurs with other conifers. Future work in linking the AVIRIS derived forest cover distributions with other data in a spatial analysis may provide useful tools for grizzly bear habitat delineation.

The 1996 AVIRIS image of forest cover for the area around Mammoth Hot Springs was also examined, revealing that the forest cover is, again, predominately lodgepole pine of various age classes. In the northern part of the scene, near Mammoth Hot Springs, large stands of Douglas fir were detected and mapped. These stands were also indicated in the air photo interpretations of Despain (1990). In another area of the scene, around Mount Everts, there was disagreement between the AVIRIS and air photo maps. The spectral feature analysis identified many pixels as SF and DF. However, the air photo analysis showed only DF in this area. Upon field checking, it was found that, in addition to the indicated DF, there were many large stands of Engelmann spruce (subalpine fir was not present). Thus, the spectral analysis was consistent in identifying the best match to these stands as the SF cover type.

Elsewhere in the Mammoth scene, the distribution of various age classes of lodgepole pine were mapped. Though the majority of lodgepole pine in the scene consists of young seedlings reestablishing after the 1988 fires, a triangular shaped patch of older lodgepole pine was clearly mapped in the southeast corner of the Mammoth scene. The trees in this stand were identified as falling into two age categories: 45-150-year-old LP1 and 150-300-year-old LP2. The identified age classes of lodgepole pine derived from AVIRIS data match the age classes indicated in the maps compiled from air photo interpretations; however, the spatial patterns differ. The age classes are divisions of a continuous series. Thus, different age categories may need to be developed for spectral remote sensing data. These age classes would need to correspond to consistently observable differences in canopy spectra that result from physical changes such as species composition, canopy structure, and percent cover of forest stands. A field study linking forest age and structure with AVIRIS canopy reflectance is suggested to explore more detailed application of AVIRIS to the discrimination of the ages of lodgepole pine stands. This study represents a simple, first step in using spectral feature analysis to map vegetation types. Future studies might exploit additional spectral features or characteristics (such 


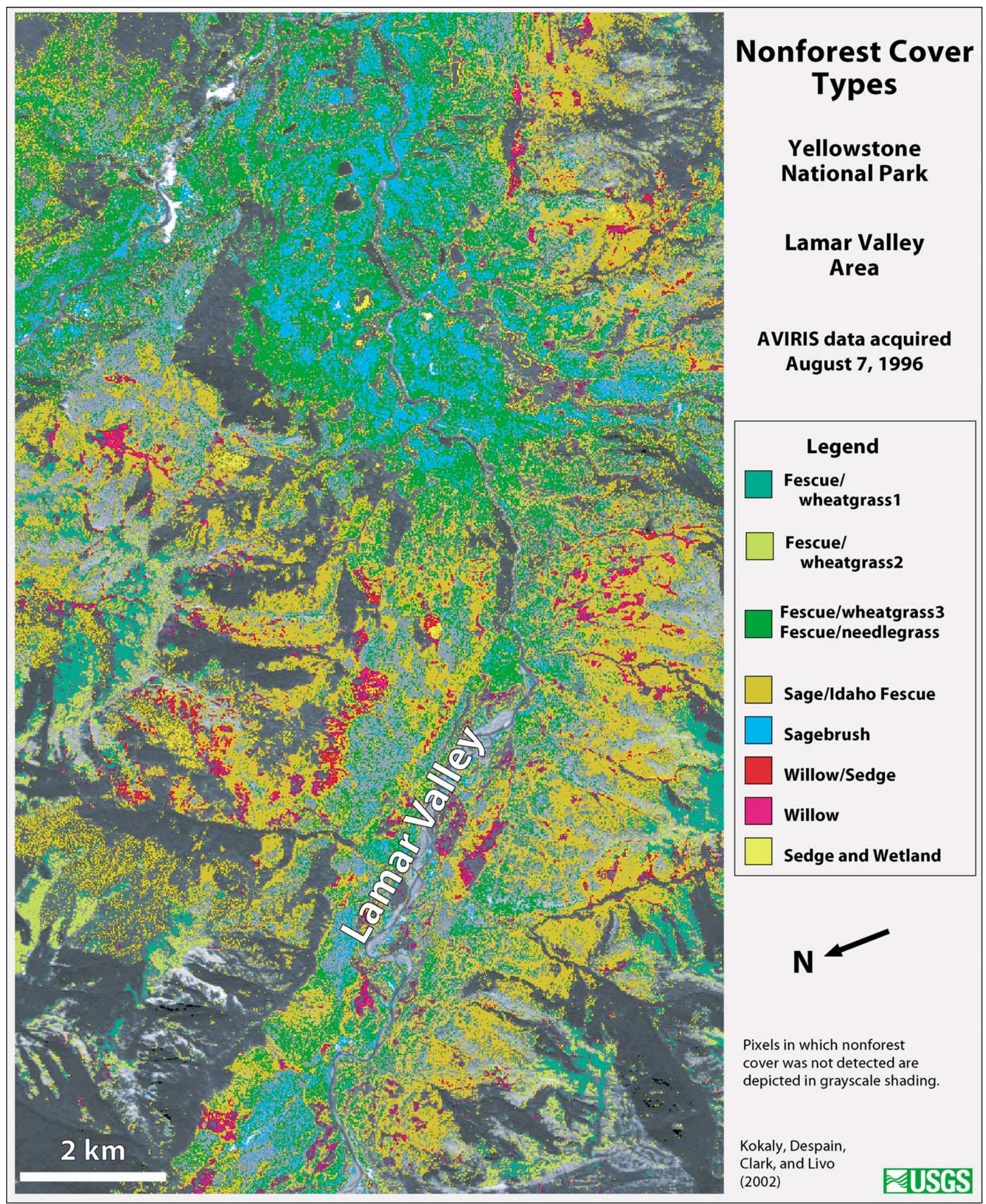

Fig. 9. Map of nonforest cover types for the Lamar Valley area of Yellowstone National Park derived from AVIRIS data and the USGS Tetracorder expert system. 
as continuum slope or band depth constraints) beyond the three absorption features used here.

During a preliminary examination of areas burned by the 1988 fires, it was noted that some areas of LP0 age class showed very strong chlorophyll and water absorption features in the 1996 AVIRIS data. As a result, the LP0 class was divided into two categories: moderate and vigorous regrowth (see the entries in Table 1). When the Tetracorder results were examined for the Mammoth Hot Springs area, several large areas were identified with a high concentration of the vigorous lodgepole pine regrowth. These areas were checked by field survey and the lodgepole pines in these areas were observed to have grown to greater heights and densities than the surrounding lodgepole pine regrowth. The areas of vigorous growth had high soil moisture that may offer a partial explanation for the higher growth rates. The spectral differences may be explained by the seedling densities in the two areas. Areas of slower regrowth were a mix of grass cover and lodgepole pine seedlings. Areas of vigorous regrowth had nearly full cover by lodgepole pine. The spectrum of the vigorous regrowth was intermediate between the slower growing LP0 age class and the older LP1 age class.

\subsubsection{Nonforest cover}

The results of mapping nonforest vegetation cover types in Yellowstone using AVIRIS data are shown for the Lamar Valley in Fig. 9. Sagebrush shrublands were mapped primarily in the upper central part of the image at low elevations in the Lamar Valley and less frequently at higher elevation areas. The sagebrush shrublands mapped at the lower elevations of the Lamar Valley (cyan color in Fig. 9) matched the sage 1 and sage 2 training sites. The higher slopes of the valley matched the training sites that had a higher percentage of grass relative to sagebrush (corresponding to entries of sage/fescue 1 and sage/fescue 2 listed in Table 2 and the light orange pixels in Fig. 9).

Along with the sagebrush cover types, much of Lamar Valley contains Idaho fescue grasslands which are mixed with other grasses. Idaho fescue, Richardsons needlegrass and bluebunch wheatgrass (fescue/needlegrass and fescue/ wheatgrass3) were found to be present in the sagebrush areas in the lower elevations of the valley. At higher elevations, Idaho fescue and bearded wheatgrass were prevalent. Two subcategories of this grassland were distinguished: the drier bearded wheatgrass phase (fescue/wheatgrass2) and the moist sticky geranium phase (fescue/ wheatgrass1). These two cover types were mapped at higher elevations in the scene compared to the other grasslands. These closely related cover types occur near each other but with distinct boundaries. Possibly, the undulating terrain of the valley affects the distribution of the wet phase, causing it to occur in depressions and areas of greater snow accumulation that remain wetter throughout the year. The riparian vegetation types (willows, sedges, and wetlands) mapped as expected along streams and rivers. The maps show reasonable distribution patterns based on coarse field surveys, but no accuracy assessment was performed due to lack of appropriate reference data. These maps of nonforest cover types produced from AVIRIS data could have important application by National Park Service personnel for assessing winter grazing resources for the large mammals in the park, for example bison and elk. These maps combined with other data could lead to a better understanding of the movements of mammal populations within and beyond the park boundaries.

The spectra of nonforest vegetation can change drastically throughout the seasons; as a result, the spectral signatures of the vegetation cover types derived from this specific flight will not necessarily have the same reflectance characteristics at different times of the year and in different years. For example, deciduous plants drop their leaves at the end of the season and grow new ones in the spring. The size and biochemical composition of leaves vary through the season, thus altering the leaf reflectance. In addition, interannual variation in reflectance may occur for the same time in the growing season because of local factors such as precipitation or temperature.

For evergreen conifer forests, the temporal changes of reflectance may be less than for other vegetation types. However, during the year, the conifers change morphologically. In the spring, new needles are produced (commonly of a lighter shade of green). In the fall and winter, needle drop occurs. The spectral library derived from this study was used to map conifer cover types in the Old Faithful area of Yellowstone (primarily lodgepole pine) using calibrated low altitude AVIRIS data $(1.5 \mathrm{~m}$ pixel size $)$ that was acquired on October 13, 1998 (Kokaly, Clark, Despain, \& Livo, 2001). The results of that study showed that the mean remotely sensed reflectance spectra of lodgepole pine stands had differences in overall reflectance levels, because of changing view and illumination angles. However, the shapes of the chlorophyll absorption features in the 1996 high altitude and 1998 low altitude AVIRIS data were similar. Kokaly et al. (2001) showed that the application of the Tetracorder expert system with the spectral library derived from the 1996 high altitude data resulted in similar mapping of conifers in the 1998 low altitude data.

\section{Conclusions}

Maps of vegetation types in Yellowstone National Park were made using Airborne Visible/Infrared Imaging Spectrometer (AVIRIS) data calibrated to ground reflectance, an image-derived spectral library of vegetation, and the USGS Tetracorder expert system. An essential element of this approach was spectral feature analysis of the $0.68 \mu \mathrm{m}$ chlorophyll and the 0.98 and $1.20 \mu \mathrm{m}$ water absorption features present in the spectra of vegetation. Forest cover 
types of whitebark pine, Douglas fir, Engelmann spruce/ subalpine fir, and lodgepole pine were identified and mapped. Whitebark pine, an important resource for grizzly bears, was mapped on the slopes of Mount Washburn. In this area of Yellowstone, the forest cover maps produced from the AVIRIS data agreed with air photo interpretations by Despain (1990) to an overall level of 74.1\% (kappa statistic $=0.62$ ). Regrowth of lodgepole pine from the fires of 1988 was differentiated from older lodgepole pine stands. Variations in the spectral signatures of lodgepole pine regrowth from the 1988 fires were observed. Representative spectra of these variations were used to discriminate between and map occurrences of moderate and vigorous regrowth. In the Lamar Valley of Yellowstone, nonforest vegetation types were mapped, including sagebrush, wetlands, and various associations of grasslands.

In this study, reflectance signatures of the vegetation cover types in Yellowstone were created by averaging the spectra of AVIRIS pixels. The reflectance spectra of these cover types showed variation in the strengths and shapes of the chlorophyll and leaf water absorption features. The absorption strengths, as measured by continuum removed band depths, increased from the moderate absorption strengths in stands of lodgepole pine to the strongest absorption by Douglas fir forests. Reflectance signatures of lodgepole pine age classes showed variation in the near infrared plateau region $(0.7-1.3 \mu \mathrm{m})$, including increasing water absorption and decreasing continuum slope from young to middle age to old growth stands. Compared to inter-species differences, the spectra of older lodgepole pine stands (from 45 to 300 years of age) had less distinct changes in their absorption features. Additional research on spectral discrimination of age classes of lodgepole pine is warranted.

The success of a spectral feature analysis approach applied to the remote sensing of vegetation was demonstrated. Specifically, continuum removal was used for normalization and linear least-squares fitting was used for comparison of spectral features in the USGS Tetracorder expert system. Other algorithms that focus on the shapes of spectral features should produce similar results. This analysis of AVIRIS data showed that advances in remote sensing, leading to the development of airborne imaging spectrometers, have resulted in a tool applicable to studying many parts of Yellowstone National Park ecosystems.

\section{Acknowledgements}

The authors would like to acknowledge the assistance of the staff at Yellowstone National Park. In particular, Ann Rodman consistently provided valuable support. The authors appreciate the contributions of Jeannette Arce and Sheldon Selwyn in georeferencing data sets and enduring long days of fieldwork. We offer our gratitude to Rob Green and the AVIRIS team for their excellence in the calibration and operation of the AVIRIS instrument. Finally, the anonymous reviewers supplied detailed and insightful comments that greatly improved the original manuscript. This work was supported by the Minerals Program of the US Geological Survey.

\section{References}

Adams, J. B., Smith, M. O., \& Gillespie, A. R. (1993). Imaging spectroscopy: interpretation based spectral mixture analysis. In C. M. Pieters, \& P. A. Englert (Eds.), Remote geochemical analysis: elemental and mineralogical composition (pp. 145-166). Cambridge: Cambridge Univ. Press.

Asner, G. P., \& Lobell, D. B. (2000). A biogeophysical approach for automated SWIR unmixing of soils and vegetation. Remote Sensing of Environment, 74, 99-112.

Blackburn, G. A. (1998). Quantifying chlorophylls and carotenoids at leaf and canopy scales: an evaluation of some hyperspectral approaches. Remote Sensing of Environment, 66, 273-285.

Boardman, J. W., \& Goetz, A. F. H. (1991). Sedimentary facies analysis using AVIRIS data: a geophysical inverse problem. In R. O. Green (Ed.), Proceedings of the 3rd airborne visible/infrared imaging spectrometer (AVIRIS) workshop. JPL Publication, 93-26, 11-14.

Byrt, T., Bishop, J., \& Carlin, J. B. (1993). Bias, prevalence, and kappa. Journal of Clinical Epidemiology, 46, 423-429.

Clark, R. N. (1999). Spectroscopy of rocks and minerals and principles of spectroscopy. In A. N. Rencz (Ed.), Remote sensing for the earth sciences: manual of remote sensing, vol. 3 (3rd ed., pp. 3-58). New York: Wiley.

Clark, R. N., Gallagher, A. J., \& Swayze, G. A. (1990). Material absorption band depth mapping of imaging spectrometer data using a complete band shape least-squares fit with library reference spectra. In R. O. Green (Ed.), Proceedings of the second airborne visible/infrared imaging spectrometer (AVIRIS) workshop. JPL Publication, 90-54, 176-186.

Clark, R. N., \& Roush, T. L. (1984). Reflectance spectroscopy: quantitative analysis techniques for remote sensing applications. Journal of Geophysical Research, 89, 6329-6340.

Clark, R. N., \& Swayze, G. A. (1995). Mapping minerals, amorphous materials, environmental materials, vegetation, water, ice and snow, and other materials: the USGS Tricorder algorithm. In R. O. Green (Ed.), Summaries of the fifth annual JPL airborne earth science workshop. JPL Publication, 95-1, 39-40.

Clark, R. N., Swayze, G. A., Heidebrecht, K. B., Goetz, A. F. H., \& Green, R. O. (1993). Comparison of methods for calibrating AVIRIS data to ground reflectance. In R. O. Green (Ed.), Summaries of the 4th annual JPL airborne geosciences workshop, vol. 1: AVIRIS workshop. JPL Publication, 93-26, 31-34.

Clark, R. N., Swayze, G. A., Livo, K. E., Kokaly, R. F., Sutley, S. J., Dalton, J. B., McDougal, R. P., \& Gent, C. A. (2002a). Imaging spectroscopy: earth and planetary remote sensing with the USGS Tetracorder and expert system. Journal of Geophysical Research (in press).

Clark, R. N., Swayze, G. A., Livo, K. E., Kokaly, R. F., King, T. V. V., Dalton, J. B., Vance, J. S., Rockwell, B. W., Hoefen, T., \& McDougal, R. R. (2002b). Surface reflectance calibration of terrestrial imaging spectroscopy data: a tutorial usinf AVIRIS. In R. O. Green (Ed.), Proceedings of the 11th JPL Airborne Science Workshop. JPL Publication (in press).

Cohen, J. (1960). A coefficient of agreement for nominal scales. Educational and Psychological Measurement, 20, 37-46.

Congalton, R. G., \& Mead, R. A. (1983). A quantitative method to test for consistency and correctness in photointerpretation. Photogrammetric Engineering and Remote Sensing, 49, 69-74.

Despain, D. G. (1990). Yellowstone vegetation: consequences of environment and history in a natural setting. Santa Barbara: Roberts Rinehart Publishers. 
Elvidge, D. E. (1990). Visible and near infrared reflectance characteristics of dry plant materials. Remote Sensing of Environment, 11, 1775-1795.

Gao, B. C. (1996). NDWI-A normalized difference water index for remote sensing of vegetation liquid water from space. Remote Sensing of Environment, 58, 257-266.

Gao, B. C., Heidebrecht, K. B., \& Goetz, A. F. H. (1993). Derivation of scaled surface reflectance from AVIRIS data. Remote Sensing of Environment, 44, 165-178.

Gao, B. C., Heidebrecht, K. B., Goetz, A. F. H. (1997). Atmosphere removal program (ATREM) Version 3.0 user's guide (pp. 1-27). Center for the Study of Earth from Space, University of Colorado at Boulder.

Gates, D. M., Keegan, H. J., Schleter, J. C., \& Weidner, V. R. (1965). Spectral properties of plants. Applied Optics, 4, 11-20.

Green, R. O., Eastwood, M. L., Sarture, C. M., Chrien, T. G., Aronsson, M., Chippendale, B. J., Faust, J. A., Pavri, B. E., Chovit, C. J., Solis, M., Olah, M. R., \& Williams, O. (1998). Imaging spectroscopy and the Airborne Visible/Infrared Imaging Spectrometer (AVIRIS). Remote Sensing of Environment, 65, 227-248.

Ingle, J. D. (1988). Spectrochemical analysis (pp. 424-425). Engelwood Cliffs, NJ: Prentice-Hall.

Jakubauskas, M. E. (1996). Thematic Mapper characterization of lodgepole pine seral stages in Yellowstone National Park, USA. Remote Sensing of Environment, 56, 118-132.

Kimes, D. S. (1983). Dynamics of directional reflectance factor distributions for vegetation canopies. Applied Optics, 22, 1364-1372.

King, T. V. V., Clark, R. N., \& Swayze, G. A. (2000). Applications of imaging spectroscopy data: a case study at Summitville, Colorado. In F. Kuehn, T. V. V. King, B. Hoerig, \& D. C. Peters (Eds.), Remote sensing for site characterization (pp. 164-185). New York: Springer.

Knipling, E. B. (1970). Physical and physiological basis for the reflectance of visible and near-infrared radiation from vegetation. Remote Sensing of Environment, 1, 155-159.

Kokaly, R. F. (2001). Investigating a physical basis for spectroscopic estimates of leaf nitrogen concentration. Remote Sensing of Environment, $75,153-161$.

Kokaly, R. F., \& Clark, R. N. (1999). Spectroscopic determination of leaf biochemistry using band-depth analysis of absorption features and stepwise multiple linear regression. Remote Sensing of Environment, 67, 267-287.

Kokaly, R. F., Clark, R. N., Despain, D. G., \& Livo, K. E. (2001). The effects of temporal sampling and changing spatial scales on the mapping of forest cover in Yellowstone National Park using imaging spectroscopy. In R. O. Green (Ed.), Proceedings of the 10th JPL airborne earth science workshop. JPL Publications, 02-1, 239-252.

Kokaly, R. F., Clark, R. N., \& Livo, K. E. (1998). Mapping the biology and mineralogy of Yellowstone National Park using imaging spectroscopy. In R. O. Green (Ed.), Summaries of the 7th annual JPL airborne earth sciences workshop. JPL Publications, 97-21, 245-254.

LaCapra, V. C., Melack, J. M., Gastil, M., \& Valeriano, D. (1996). Remote sensing of foliar chemistry of inundated rice with imaging spectrometry. Remote Sensing of Environment, 55, 50-58.

Martin, M. E., \& Aber, J. D. (1997). High spectral resolution remote sensing of forest canopy lignin, nitrogen and ecosystem process. Ecological Applications, 7, 431-443.

Martin, M. E., Newman, S. D., Aber, J. D., \& Congalton, R. G. (1998). Determining forest species composition using high spectral resolution remote sensing data. Remote Sensing of Environment, 65, 249-254.
Mattson, D. J., Blanchard, B. M., \& Knight, R. R. (1992). Yellowstone grizzly bear mortality, human habituation, and whitebark pine seed crops. Journal of Wildlife Management, 56, 432-442.

Mattson, D. J., \& Reinhart, D. P. (1997). Excavation of red squirrel middens by grizzly bears in the whitebark pine zone. Journal of Applied Ecology, 34, 926-940.

Mustard, J. F., \& Pieters, C. M. (1987). Abundance and distribution of ultramafic microbreccia in Moses Rock Dike: quantitative applications of imaging spectrometer data. Journal of Geophysical Research, 94, $13619-13634$.

Mustard, J. F., \& Sunshine, J. M. (1999). Spectral analysis for Earth science investigation. In A. N. Rencz (Ed.), Remote sensing for the earth sciences: manual of remote sensing, vol. 3 (3rd ed., pp. 251-306). New York: Wiley.

Penuelas, J., Pinol, J., Ogaya, R., \& Filella, I. (1997). Estimation of plant water concentration by the reflectance Water Index WI (R900/970). International Journal of Remote Sensing, 18, 2869-2875.

Peterson, D. L., \& Hubbard, G. S. (1992). Scientific issues and potential remote sensing requirements for plant biogeochemical content. Journal of Imaging Science and Technology, 36, 445-455.

Roberts, D. A., Gardner, M., Church, R., Ustin, S., Scheer, G., \& Green, R. O. (1998). Mapping chaparral in the Santa Monica Mountains using multiple endmember spectral mixture models. Remote Sensing of Environment, 65, 267-279.

Rockwell, B. W., Clark, R. N., Livo, K. E., McDougal, R. R., Kokaly, R. F. (2002). AVIRIS data calibration information: Wasatch Mountains and Park City Region, Utah. US Geological Survey Open File Report 02199, 12 pp.

Salisbury, J. W., Milton, N. M., \& Walsh, P. A. (1987). Significance of nonisotropic scattering from vegetation for geobotanical remote sensing. Remote Sensing of Environment, 8, 997-1009.

Swayze, G. A., Smith, K. S., Clark, R. N., Sutley, S. J., Pearson, R. M., Vance, S. J., Hageman, P. L., Briggs, P. H., Meier, A. L., Singelton, M. J., \& Roth, S. (2000). Using imaging spectroscopy to map acid mine waste. Environmental Science \& Technology, 34, 47-54.

Thenkabail, P. S., Smith, R. B., \& De Pauw, E. (2000). Hyperspectral vegetation indices and their relationships with agricultural characteristics. Remote Sensing of Environment, 71, 158-182.

Tsai, F., \& Philpot, W. (1998). Derivative analysis of hyperspectral data. Remote Sensing of Environment, 66, 41-51.

Turner, M. G., Hargrove, W. W., Gardner, R. H., \& Romme, W. H. (1994). Effects of fire on landscape heterogeneity in Yellowstone National Park, Wyoming. Journal of Vegetation Science, 5, 731-742.

Van Der Meer, F., \& Bakker, W. (1997). CCSM: cross correlogram spectral matching. International Journal of Remote Sensing, 18, 1197-1201.

Vane, G., Duval, J. E., \& Wellman, J. B. (1993). Imaging spectroscopy of the Earth and other solar system bodies. In C. M. Pieters, \& P. A. Englert (Eds.), Remote geochemical analysis: elemental and mineralogical composition (pp. 121-143). Cambridge: Cambridge Univ. Press.

Wessman, C. A., Aber, J. D., \& Peterson, D. L. (1989). An evaluation of imaging spectrometry for estimating forest canopy chemistry. International Journal of Remote Sensing, 10, 1293-1316.

Zagolski, F., \& Gastellu-Etchegorry, J. P. (1995). Atmospheric corrections of AVIRIS images with a procedure based on inversion of the $5 \mathrm{~S}$ model. International Journal of Remote Sensing, 16, 3115-3146. 